\title{
Sultan II. Mustafa için yazılan şiirler mecmuası
}

\section{Zahide EFE $^{1}$}

\begin{abstract}
APA: Efe, Z.. (2020). Sultan II. Mustafa için yazılan şiirler mecmuası. RumeliDE Dil ve Edebiyat
\end{abstract} Araştırmaları Dergisi, (19), 460-493. DOI: 10.2900o/rumelide.752433.

\section{$\ddot{O} \mathbf{z}$}

Klasik Türk edebiyatında divan ve mesnevilerle birlikte en önemli eser türlerinden biri de mecmualardır. Klasik Türk edebiyatının önemli kaynakları arasında yer alan mecmualar sahip oldukları şekil, dil ve muhteva itibarıyla birtakım sınıflandırmalara tabi tutulmuşlardır. Bu sınıflandırmalarda yer alan mecmua türlerinden biri de belli şahıslar adına tertip edilmiş olanlardır. Bu tarz mecmualar genellikle padişahlar ve devlet adamları adına tertip edilmiştir. Bu özellikleri haiz olan mecmulardan biri de Nuruosmaniye Kütüphanesi’nde 3700 numarada kayıtlı olan ve Sultan II. Mustafa için yazılan şiirleri ihtiva eden Mecmûa-i Tevârîh'tir. Bu eserde, II. Mustafa'nın cülûsu ve Sakız Adası'nın fethi münasebetiyle 17. yüzyılın sonu ile 18. yüzyılın ilk çeyreğinde yaşamış olan 67 farklı şair tarafından kaleme alınan 100 manzume bulunmaktadır. Bu manzumeler edebî açıdan önemli oldukları kadar yazıldıkları dönemin tarihî ve toplumsal olaylarına ışık tutmaları bakımından da oldukça önemlidir. Bu çalışmada öncelikli olarak Mecmûa-i Tevârîh'in şekil ve muhteva özellikleri üzerinde durularak birtakım değerlendirmelerde bulunulmuştur. Ardından mecmuada yer alan şiirlerden bazı örnekler verilerek mecmuadaki şiirlerin MESTAP'a göre tasnifi yapılmıştır.

Anahtar kelimeler: Klasik Türk edebiyatı, mecmua, II. Mustafa, cülûsiyye, Sakız’ın fethi

\section{The journal of poems which were made for Sultan Mustafa II}

\begin{abstract}
One of the most important work types is the journals with the divan and mesnevi in The Classical Turkish literature. The journals which are among the important sources in The Classical Turkish literature were subjected to a set of classifications by means of their form, language and content. One of these journal types in these classifications is those which were formed on behalf of the certain persons. Such journals were generally formed on behalf of the padishahs and statesmen. One of the journals with these features is Mecmûa-i Tevârîh which is recorded in 3700 no. In Nuruosmaniye Library and contains the poems that were written for Sultan Mustafa II. In this work, 100 poems which were written by 67 poets who lived at the end of 17 th century and at the first quarter of 18 th century are available on the occasion of Mustafa II's enthronement and the conquest of Sakiz. These poems are important in terms of literature for the history of period when they were written and as they enlightened the social events. In this research, Mecmûa-i Tevârîh's form and content features were firstly emphasized, and a set of evaluations were made. Next, the poems in the journal were classified according to MESTAP as some of their samples in the journal were given.
\end{abstract}

Keywords: Classical Turkish literature, mecmua, Mustafa II, cülûsiyye, conquest of Sakız

1 Ar. Gör., Osmaniye Korkut Ata Üniversitesi, Fen Edebiyat Fakültesi, Türk Dili ve Edebiyatı Bölümü (Osmaniye, Türkiye), zahide_efe@outlook.com, ORCID I0.2900o/rumelide.752433] 


\section{Giriş}

Çeşitli şekil ve türlerdeki eserleri bir araya getirerek zengin muhtevaları ile ön plana çıan ve kütüphanelerde oldukça fazla örneği bulunan mecmualar, klasik Türk edebiyatı çalışmaları için oldukça ehemmiyeti haiz eserlerdir. Mecmualar üzerine yapılan ilmî çalışmaların² artması neticesinde birçok araştırmacı tarafından mecmualar hem şekil hem de muhteva itibarıyla birtakım sınıflandırmalara 3 tabi tutulmuştur. Bu sınıflandırmalarda muhteva bakımından karşımıza çıkan mecmua türlerinden biri de şahısların tertip ettiği ${ }^{4}$ veya şahıslar için tertip edilen mecmualardır. Yapılan ilmî çalışmalar neticesinde gün yüzüne çıkan ve belli şahıslar adına tertip edilmiş olan mecmua örneklerinden bazıları hakkında aşağıda bilgi verilmiştir. Yapılacak olan yeni çalışmalarla bu tarz mecmuaların sayısının artacağı muhakkaktır.

I. Mahmûd için yazılan şiirler mecmuası: Topkapı Sarayı Müzesi Kütüphanesi’nde (Revan 1977) bulunan bu mecmua, Hıfzî Ağa tarafından 1143-44/1730-32 tarihleri arasında derlenmiştir. Mecmua, iki bölümden oluşmaktadır. I. Mahmûd'un doğumu, derse başlaması, sakal bırakması, tahta çıması, 1144/1731 senesinin gelmesi ve padişah hakkında yazılmış çeşitli şiirlerden meydana gelen birinci bölümde 53 değiş̧ik şairin şiiri yer almaktadır. Mecmuanın ikinci bölümünde ise Hıfzînnin yazmış olduğu III. Ahmed'in tahttan indirilişi ile I. Mahmûd'un padişah olması sırasında İstanbul'da meydana gelen olaylar hakkında gün gün bilgi veren mensur Rûznâme yer almaktadır (Aynur ve Şen 2019: 39-73).

Sultan I. Ahmed methiyeleri: Fransa Milli Kütüphanesi, Türkçe Yazmalar Bölümü 1035 numarada kayıtlı olan bu şiir mecmuasının tamamına yakını Sultan I. Ahmed için yazılan methiyelerden oluşmaktadır. Mecmuada, 16. ve 17. yüzyıldan 37 şaire ait 213 Türkçe şiir bulunmaktadır (Yıldız ve Batur 2019: 17-72).

Ahmed Hasîb Efendi’nin Mecmû'a-i Tevârîh’i: Süleymaniye Kütüphanesi, Esad Efendi Bölümü 3388 numarada kayıtlı olan bu mecmua, Hekimoğlu Ali Paşa için yazılan şiirleri ihtiva etmektedir. Hekimoğlu Ali Paşa, 1155/1742 senesinde ikinci kez sadrazam olduğunda devrin pek çok şairi bu tayini tebrik ve tebşir niyetiyle kasideler ve tarih manzumeleri kaleme almışlardır. Ali Paşa kendisine takdim edilen bu manzumelerin bir araya getirilmesi işini Ahmed Hasîb Efendi'ye vermiştir. Ahmed Hasîb

2 Mecmualarla ilgili yapılan ilmî çalışmaları daha derli toplu bir hale getirerek okuyucu ve araştırmacıların hizmetine sunmak maksadıyla 3 Mayıs 2011 tarihinde "Mecmua: Osmanlı Edebiyatının Kırkambarı" başlı̆̆ altında bir sempozyum düzenlenmiştir. Ardından 30 Haziran 2012 tarihinde Atatürk Kültür Merkezi Başkanlığının himayesinde "Osmanh Siirinin Hazineleri: Mecmualar ve Cönkler Calıstay”" ve 27-28 Ekim 2017 tarihlerinde "MESTAP (Siir Mecmualarmın Tasnifi Projesi) Çalıştayı” gerçekleştirilmiştir. Fatih Köksal'ın öncülüğünde başlatılan Mecmuaların Sistematik Tasnifi Projesi (https://mestap.com) ile mecmualarla ilgili yapılan çalışmaların sayısı artmakla birlikte daha sistemli bir hale dönüsmüstür.

3 Mecmuaların sınıflandırılması hususunda bkz. Kılıç, A. (2012), "Mecmûa Tasnifine Dâir” Eski Türk Edebiyatı Çalşşmaları VII: Mecmûa: Osmanl Edebiyatını Krrkambarı, (hazırlayanlar: Hatice Aynur ve öte.), Turkuaz, Istanbul, s. 75-96; Köksal, M. Fatih, (2012). "Şiir Mecmualarının Önemi ve Mecmuaların Sistematik Tasnifi Projesi (MESTAP)”, Eski Türk Edebiyatında Tenkit ve Teori, İstanbul: Kesit Yayınları. s. 83-101; Gürbüz, M. (2012), "Şiir Mecmûaları Üzerine Bir Tasnif Denemesi”, Eski Türk Edebiyat Calıșaları VII: Mecmûa: Osmanlı Edebiyatının Kırkambarı, (Haz.: Hatice Aynur vd.), İstanbul: Turkuaz Yayın. s. 97-113; Levend, A. Sırrı (1998). Türk Edebiyatı Tarihi, I. Cilt. Ankara: Türk Tarih Kurumu. s. 166-67; Kut, G. (1986). "Mecmua". Türk Dili ve Edebiyatı Ansiklopedisi. C. 6. İstanbul: Dergâh Yay. s. 170; Kurnaz, C. ve Aydemir, Y. (2013). Mecmualara Sorulması Gereken Sorular. Turkish Studies, 8 (1), s. 53; Koncu, H. ve Çakır, M. (2012). Şairleri Yetiştiren Bir Kaynak Olarak Mecmua. Eski Türk Edebiyatı Çahşmaları VII, Mecmûa: Osmanh Edebiyatının Krrkambarı, İstanbul: Turkuaz, s. 120; Uzun, M. (2003). “Mecmua”. İslam Ansiklopedisi. C. 28. Ankara: TDV Yay. s. 265. Mecmuaların çoğunluğunun derleyeni belli olmamakla birlikte belli şahıslar tarafindan tertip edilen mecmualar da bulunmaktadır. Pervane Bey'in Mecmûa-i Nezâir’ì (Glynaş 2017), Edirneli Nazmî’nin Mecma‘u’n-Nezẩỉ’i (Köksal 2017) ve Eğridirli Hacı Kemal'in Câmiü’n-Nezâir'i (Ertek Morkoç 2003) gibi nazire mecmualarının yanında Nigînî Mecmuası (İçli 2017), Kasımî Mecmuası (İçli 2018), İshak-zâde Fevzî Mecmuası (Köksal 2016) gibi belli şahıslar tarafından tertip edilen mecmualar da bulunmaktadır. 
Efendi, 1155/1742 senesinde derlemeye başladığı mecmuayı yaklaşık bir sene zarfında tamamlamıştır. Mecmûa-i Tevârîh'te 60 şaire ait 112 civarında manzume yer almaktadır (İnan 2013).

Vekâyi'-i Ali Paşa: Eserin biri Türkiye'de, iki tanesi Daru'l-Kütübi Mısriyye’de, bir tanesi de Bibliotheque Nationale de France (Fransa Milli Kütüphanesi) de olmak üzere dört nüshası bulunmaktadır. Kelâmî-i Rûmî tarafından kaleme alınan eser, 1601-1603 yılları arasında Mısır valiliği yapan Yavuz Ali Paşa adına kaleme alınmıştır. Eser, iki bölümden oluşmaktadır. İlk bölümde Ali Paşa'nın Mısır valiliği sırasındaki icraatleri anlatılmaktadır. İkinci bölüm ise Ali Paşa'nın Kelâmı̂’den devrin şairlerinin yazdığı kasideler ve beyitleri bir araya toplaması isteği üzerine kaleme alınmıştır. Kelamî, devrin şairlerinin Ali Paşa hakkında yazdığı kaside, gazel, tarih, kıt'a, terci-i bend gibi nazım şekilleriyle kaleme alınmış şiirleri bir araya getirmiştir (Demirsoy 2010).

Fâiz Efendi ve Şâkir Bey mecmuası: Halet Efendi Kitaplığı, 763 numarada kayıtlı olan bu mecmua, Üçüncü Ahmed ve Nevşehirli Damat İbrahim Paşa adına Fâiz Efendi ve Şâkir Bey tarafından tertip edilmiştir. Mecmuada Üçüncü Ahmed ve İbrahim Paşa adına yazılmış toplam 502 şiir mevcuttur. Bu şiirlerden 242 tanesi İbrahim Paşa'ya yazılmış kasidelerdir. Toplam 98 şairin bulunduğu mecmuada, 82 şairin İbrahim Paşa'ya yazılmış kasidesi mevcuttur. Ayrıca mecmuada 160 tarih, 7 terkib-i bend, 5 tercii bend, 2 müseddes, 17 manzume, 17 gazel-i müzeyyel, 2 mesnevi, 3 muaşşer, 3 tahmis, 17 Arapça tarih, 7 Arapça kaside ve 5 Farsça kaside mevcuttur (Hakverdioğlu 2007).

Defterdar Mehmed Behcet Efendi'ye sunulan şiirler mecmuası: Millet Kütüphanesi, Ali Emiri Manzum 575 numarada kayıtl olan bu mecmua, Defterdar Mehmed Behcet Efendi adına tertip edilmiştir. Mecmuada Behcet Efendi için kaside, terci-i bend, tahmis, kıt'a, gazel ve beyit nazım şekilleri ile yazılmış toplam 108 şiir bulunmaktadır. Mecmuada ramazaniyye, ıddiyye, bahariyye ve tarih gibi nazım türleri ile yazılmış manzumeler yer almaktadır. Behcet Efendi'nin 1164/1750-51 tarihinde ikinci defa defterdarlık görevine gelmesi, 1164/1750-51 tarihinde tersane amiri olmasl, 1165/1751-52 tarihinde hane inşa ettirmesi, 1155/1742-43 tarihinde kasır yaptırması, yine 1156/1743-44 tarihinde bu kasra serdâb yaptırması, 1159/1746-47 tarihinde Üsküdar'da Şeyh Yusuf Halvetî’nin tekyesini tamir ettirmesi ve 1164/1750-51 tarihinde Siroz'a gitmesi ve dönmesi için düşürülmüş tarih manzumeleri bulunmaktadır (Kaplan ve Efe 2020).

Ârif Efendi, Mecmû‘a-i Eş‘âr (III. Selim'le ilgili şiirler): İstanbul Topkapı Sarayı Müzesi Kütüphanesi, Türkçe Yazmalar Bölümü R. 827'de bulunan bu mecmua, Müderris-zâde Mehmed Ârif Efendi tarafından derlenmiştir. Mecmua'da Sultan III. Selim'e ait 1 nazm, devrin bazı şairleri, devlet adamları, çeşitli meslek erbabı tarafından III. Selim'in tahta çıkışını övmek ve bu olaya tarih düşürmek maksadıyla kaleme alınmış 69 tarih manzumesi ve 2 kaside bulunmaktadır (Özerol 2013).

Mecmû'a-i Tevârîh: Topkapı Sarayı Müzesi Kütüphanesi’nde E.H 1487 numarayla kayıtlı olan bu mecmua, Sultan II. Mustafa için yazılan şiirleri ihtiva etmektedir. Mecmuada II. Mustafa dönemi (16951703) olaylarına dair yeni ve tafsilatlı bilgiler yer almakta, XVII. yüzyılın ikinci yarısını kapsayan dönemdeki siyasî-sosyal aksaklıklar samimî bir dille yansitılmaktadır. Mecmuada bulunan tarih manzumelerinde padişahın yanında sefere giden kişilerin bir kalenin fethi esnasında şahit oldukları ana dair canlı tasvirleri yer almaktadır (Piroğlu 2019). Toplam 59 manzumenin bulunduğu bu mecmuada bizim çalışmamızın konusunu teşkil eden mecmuayla benzerlik gösteren 18 manzume bulunmaktadır. 


\section{Sultan II. Mustafa için yazılan şiirler mecmuası}

\section{Sultan II. Mustafa hakkında}

Başımızdan hiç hevâ-yı zülf-i yâr eksik değil Mürtefi' yerdir aninçün rûzgâr eksik değil

İkbâlî

II. Mustafa, Osmanlı padişahlarının yirmi ikincisi ve İslam halifelerinin seksen yedincisidir. Sultan IV. Mehmed'in oğlu olup 1074/1664 tarihinde Gülnûş Emetullah Sultan'dan İstanbul'da doğmuştur. Devrin âlimlerinden iyi bir tahsil görmüş ve Vanî Mehmet Efendi ile Seyyid Feyzullah Efendi'den ders almıştır (Çibir 2016: 13).

1106/1695 yllında amcası II. Ahmed'in vefatı üzerine tahta geçen II. Mustafa, ilk iş olarak ataları gibi bizzat ordunun başında sefere çıkma isteğini bildiren ve yapacağı işleri anlatan bir hatt-ı hümâyun yayınlamıştır. Bundan böyle kendisine zevk ve rahatı haram kıldığını, babası Sultan Mehmed'den beri padişahların eğlenceye düşmeleri ve ihmalleri yüzünden düşmanın İslam ülkelerini ele geçirdiğini, Allah'ın yardımıyla onlardan intikam almak için bizzat kendisinin gaza ve cihada niyet ettiğini belirtmiştir (Özcan 2006: 275).

II. Mustafa ilk yıllarında kısmi başarılar elde etmiş ancak daha sonraki yıllarda Macaristan, Mora, Podolya kaybedilmiştir. Padişah, devletin Gerileme Dönemi’nin en tipik hadisesi sayılan Karlofça Antlaşmasını (1699) imzalamak zorunda kalmıştır. 1700 yılında Ruslara Azak’ın bırakılmasıyla da Karadeniz bir Türk gölü olma vasfını kaybetmiş̧ir. On altı yıldan beri devam eden savaşlardan yıpranan devlet, 1703 yılında Birinci Edirne Vakası adıyla anılan ayaklanma ile birlikte büyük bir sarsıntı geçirmiştir. Padişah bu ayaklanma neticesinde tahtını kaybetmiş ve kısa bir süre sonra 29 Aralık 1703 tarihinde de vefat etmiştir (İsen vd. 2012: 178).

Çok iyi hocalardan ders alan II. Mustafa, hat sanatıyla da uğraşmış, Hocazâde Mehmed Enverî ve Hâfız Osman'dan ders almış, özellikle sülüs, nesih ve celî yazılarda başarılı örnekler vermiştir (Müstakimzâde, s. 539). IV. Murad'dan sonra gelen Osmanlı padişahları içinde en âlimi ve kültürlüsüdür. Âlimlerle sohbet etmekten hoşlanan II. Mustafa, ilme ve ilim adamlarına önem vermiş ve onları korumuştur (Çibri 2016: 13). Aynı zamanda iyi bir şair olan padişah, şiirlerinde önceleri Meftûnî, daha sonraları İkbâlî mahlasını kullanmıştır (Arkun 2010: 284).

\section{Mecmuanın şekil özellikleri}

Nuruosmaniye Kütüphanesi'nde 3700 numarada bulunan eser, Mecmûatü't-Tevârîh ismi ile kayıtlıdır. 45 varaktan müteşekkil olan mecmua, nesih hatlıdır. Kütüphane kaydına göre eserin fiziksel tavsifi şöyledir: 180x109, 119x065 mm. ölçülerine sahiptir. İçi-dışı meşin, yaldızlı salbek şemse, köşebent cetvelli, miklebli, şirazeli, cilt yaldız kaplamadır.

Her sayfa tek sütun ve 8 satırdan oluşmaktadır. Derkenarlarda da şiirler mevcuttur. Şiir başlıklarında yaldızlı metinlerde ise siyah mürekkep kullanılmıştır. Her sayfanın sonunda diğer sayfanın hangi kelimeyle başladığını gösteren reddadiyeler vardır. 40b-45a varaklarının derkenarları ve 45a varağına şiir kaydedilmemiştir. Hem bu varakların boş kalması hem de 40a varağında yer alan Naîmî mahlaslı bir şaire ait olan şiirin eksik olması mecmuanın tamamlanamadığı ve yarım kaldığı intibaını uyandırmaktadır. 1b-5a, 7a-7b, 10a-11a varakları arasında yer alan Arapça şiirler harekelidir. 
Mecmuanın 1a sayfasında Sultan III. Osman'ın mührü, yazmanın Sultan Osman tarafindan vakfedildiğini gösteren bir ibare ve "Bende-i Latîf İbrâhim Efendi” yazan bir mühür bulunmaktadır. 5

Mecmuada nazım şekilleri, kafiye ve redif gibi hususlarda belli bir tertip düzeni gözetilmemiştir. Şiir başlıklarının tamamına yakınında şairlerin mahlası zikredilmiştir. Bazı şiirlerin başlı̆̆ında ise şairle ilgili tanıtıcı ifadelere yer verilmiştir.

Mecmuada yer alan 89 Türkçe manzumenin 7 faklı nazım şekli ile yazıldığı görülmektedir. Nazım şekilleri arasında en çok kıt‘a nazım şekli ile yazılmış olan şiirler kayıtlıdır. Onu nazım ve kaside izlemektedir. Mecmuada bulunan şiirlerin nazım şekilleri ve sayıca dağılımı aşağıdaki tabloda gösterilmiştir:

\begin{tabular}{|c|c|c|}
\hline Sıra & Nazım şekli & Adet \\
\hline 1. & Kit‘a & 45 \\
\hline 2. & Nazım & 23 \\
\hline 3. & Kaside & 12 \\
\hline 4. & Mesnevi & 4 \\
\hline 5. & Terkib-i bend & 2 \\
\hline 6. & Müfred & 2 \\
\hline 7. & Koşma & 1 \\
\hline
\end{tabular}

\section{Mecmuada bulunan şairler ve şiir sayıları}

Mecmuada toplam 100 manzume bulunmaktadır. Bu manzumeler 17. yüzyılın sonu ile 18. yüzyılın ilk çeyreğinde yaşamış olan 67 farklı şaire aittir. Mecmuada yer alan manzumelerin 6'sı Arapça 5’i Farsça'dır. Mecmuda en fazla şiiri bulunan şair, 4 şiirle Hayrabolulu Mahmud'dur. Onu 3'er şiirle Nahîfí Çelebi, Mâhir Abdullah ve Müderris Süleyman izlemektedir.

Mecmuada yer alan şairlerin genel itibarıyla devrin tanınmış şairleri olmayıp padişahın yakın çevresinden ve saraya yakın kişiler oldukları görülmektedir. Manzumelerin başlıklarında yer alan "hânei hassa, der-hazîne, kethudâ-yı mehterân-ı hayme-i hassa, der-hâne-i hassa" gibi ifadeler bu şairlerin padişaha yakınlığını ve saraya aidiyetini teyit eder mahiyettedir. Bunun yanında şairlerin birçoğunun ilmiye sınıfına dâhil oldukları görülmektedir. Örneğin; Mehmed Füyûzî, Ahmed Efendi, Mâhir Abdullah, Tâlib müderrislik ve kadılık, Nahîfî hattatlık ve kâtiplik, Halîl kadılık, Zülâlî müderrislik ve kazaskerlik yapmış şairlerdir. Yine mecmuada yer alan şairlerden bazılarının Mevlevî ve Halvetî tarikatlarına mensup kişiler oldukları görülür. Bunlar arasında Enîs Recep Dede Mevlevî, Himmetzâde Abdî ise Bayramîlik ve Halvetîlik kolunun özelliklerini taşıyan Himmetîlik kolunun şeyhidir. Mustafa

5 "Nuruosmanî" denilen cami, kütüphane, medrese, imaret, sebil, çeşme ve türbeyi içine alan külliye I. Mahmud tarafindan yapılmaya başlanmış ancak külliye tamamlanamadan I. Mahmud vefat etmiştir. Yerine geçen kardeşi III. Osman tarafından I. Mahmud'un vefatına kadar Sultan Mahmud Camii, Sultan Mahmud Kütüphanesi diye yad olunan imaretlerin adları "Nuruosmanî”ye çevrilmiştir.

I. Mahmud saray hazinelerinde ve kendi hususi kütüphanesinde bulunan 5060 adet yazma ve kitabı bu kütüphaneye naklederek kendi namına vakfetmiştir. Tuğralı büyük bir mühür ve bunun altına da kitabın Sultan Mahmud tarafından vakfedildiğini tescil eden üç dört satırlık talik bir yazı evkaf müfettiși tarafindan mühr ile tasdik olunmuștur. III. Osman başa geçtiğinde her kitapta Sultan Mahmud'un büyük vakıf mührünü, tuğrayı hümayunu ve vakfiye hükmünde olan tasdikli yazıyı ihtiva eden baş sayfanın üzerine kalınca bir kâğıt yapıştırılarak eski mühür ve vakfiye yazısı kapatılmıştır. Yapıştırılan her kâğıt üzerine Sultan Osman namına hâkettirilen büyük bir mührü ve tuğrası basılmış ve bu kitapların Sultan Osman tarafından vakfedildiğini gösteren yine eskisi gibi bir ibare yazılmış ve "İbrâhim Hanif Bende-i Latîf" mührünü basan evkaf müfettişi tarafindan tasdik olunmuştur (Serezli 1948: 19-20) 
Ma'nevî Efendi Ordu-yu Hümayun'da, Vahyî Efendi ise Şeyhülharem Tekkesi'nde şeyhlik yapan şairlerdir. Bunun dışında Müstakîm Çelebi Halvetîlik, Nahîfî ve Nakşî İbrâhîm Efendi Mevlevîlik tarikatına intisap eden şairler arasındadır.

Mecmuada bazı şairler hakkında biyografik bilgiler de bulunmaktadır. Bu bilgiler, şairlerin şiirlerinin başlıklarında verilmiştir ve şairlerin nereli oldukları, kimlikleri ve meslekleri ile ilgilidir. Bu minvalde bilgi verilen şairler şunlardır: "Müezzin Abdullâh Çelebi, Mahmûd Hayrabolu, Süleymân el-Müderris, Ahmed Efendi Hâne-i Hassa, Derviş Ahmed Der-Hazîne, Nakşî İbrâhîm Efendi, Mahmûd Kankurî, İmâm-zâde Şükûfî Mehemmed, el-hâc Mehemmed Kethudâ-yı Mehterân-ı Hayme-i Hassa, Mehemmed el-Yanyevî, Füyûzî Mehemmed Efendi, Halîl el-kâdî, Himmet-zâde Abdullâh Efendi, Mâhir Abdullâh Efendi, Mehemmed Şeyhî Mevlevî Be-hâne-i Beşiktâş, Tophâneli Mehemmed Efendi, İbrâhîm Efendi Der-Hâne-i Hassa."

Şiir mecmualarının en önemli özelliklerinden biri kaynaklarda adı geçmeyen şairlerin şiirlerine yer vermeleri ve böylece unutulmuş birçok şairi gün yüzüne çıkarmalarıdır. Çalışmamızın konusunu teşkil eden mecmuada da tezkirelerde ve biyografik kaynaklarda ismine tesadüf edemediğimiz şairler bulunmaktadır. Bu şairler; Bâbî Efendi, Fakîrî Çelebi, Havfî Çelebi, Hıtâmî, İmâm-zâde Şükûfî Mehemmed, Külâhî, Mahmûd Kânkırî, Mehemmed el-Yanyevî, Mehemmed Kethudâ-yı Mehterân-ı Hayme-i Hassa, Tablî Efendi, Tophâneli Mehemmed Efendi'dir.

Mecmuada mahlası bulunmayan manzumeler de yer almaktadır. Bunlar "Târîh-i Diger Ser-bostânî-i Edirne" başlıklı kıt'a, "Târîh-i Diger Du'â-gûy" başlıklı kaside ve "Târîh-i Diger Cülûs-ı Sultân Mustafâ" başlıklı müfred olmak üzere toplam 3 manzumedir.

Aşağıdaki tabloda mecmuada şiiri bulunan şairler alfabetik olarak sıralanmış ve şiirlerinin sayıları ile varak numaraları gösterilmiştir. Bu şairlerden hakkında herhangi bir malumata vardıklarımızın hayatları hakkında dipnotta kısaca bilgi verilmiştir:

\begin{tabular}{|c|c|c|}
\hline & Mahlas & Şiir Sayısı ve Bulunduğu Varak \\
\hline 1. & Abdu'l-Bâkî & 1 manzume, vr. $\mathbf{2 1}^{\mathrm{a}}$ \\
\hline 2. & Adlî $^{6}$ & 1 manzume, vr. $5^{\mathrm{b}}$ \\
\hline 3. & Ahmed Efendi $^{7}$ & 1 manzume, vr. $10^{\mathrm{a}}$ \\
\hline 4. & Ârif $^{8}$ & 2 manzume, vr. $5^{\mathrm{b}}, 6^{\mathrm{b}}$ \\
\hline
\end{tabular}

6 Asıl adı Mehmed olan şair, İstanbul'da doğmuștur. Yeniçeri ocağında kul kethüdalığı yapan Süleyman Ağa'nın oğludur. Hatice Sultan’ın kethüdası olduğu için Divan-ı Sultanî olmuştur. Ahkâm eminliğii, taşra kâğgt eminliği, küçük kale tezkireciliği ve Divan-ı Hümayun'da yeniçeri efendiliği gibi görevlerde bulunmuştur. 1143/1731'de cizye muhasebecisi, 1143/1731'de tekrar tersane emini olmuştur. Sâlis defterdarlı̆̆ görevinde de bulunan Adlî’nin son görevi 1151/1739'da atandığı Rikab-ı Hümayun kâtipliğidir. 1156/1743-44 tarihinde vefat etmiştir (Kesik, Beyhan 2014). Mehmed Adli Dîvânı yüksek lisans tezi olarak çalışılmıştır (Baltalı, Seval 2016). Mecmuada yer alan Adlî̀ye ait manzume şairin Dîvân'ında yer almaktadır.

7 Asıl adı Ahmed olup Çerkez asıllıdır. Vezir Abdî Paşa'nın hazinedarı Abdî Ağa’nın kölelerindendir. Silahşör, cündî, sühanșinâs olmakla ve Paşa'nın da yardımıyla saraya dâhil olmus ve önce hazine odasına, daha sonra Has odaya ulaşarak terbiye almış ve ilmî eksiklilerini tamamlamıştır. 1117/1705-06'da vefat etmiştir (Aksoyak, İ. Hakkı 2014). Mecmuada yer alan manzumenin başlı̆̆ındaki "Ahmed Efendi Hâne-i Hassa" ibaresi şiirin Devletî mahlaslı Ahmed Efendi'ye ait olduğuna isaret etmektedir.

8 Asıl adı Mehmed olup İstanbul'da doğmuştur. Önceleri Âhî mahlası ile gazel, kaside ve tarihler yazmıştır. Daha sonra dostlarının önerisi ile Ârif mahlasını kullanmaya bașlamıștır. Zarif ve hoșsohbet birisi olduğu için bazı devlet adamlarının nedîmi ve musahibi olmuştur. Tarih düşürmede ustadır. Sultan II. Mustafa döneminde vezir Amcazâde Hüseyin Paşa'nın İstanbul Saraçhane'de yaptırdı ğı medrese, sebil ve türbeye tarih düşürmüştür (Selçuk, Bahir 2014). Tuhfe-i Nâiili’’de Enderunlu Ârif Bey’in II. Mustafa devri şairlerinden olduğu belirtilmiştir (Kurnaz ve Tatc1 2001: 608). Tezkirelerde ve biyografik kaynaklarda Ârif mahlasını kullanan birçok şair bulunmakla birlikte bu bilgiler göz önünde bulundurulduğunda mecmuada şiiri bulunan Ârif Bey’in bu zat olduğu tahmin edilebilir. 


\begin{tabular}{|c|c|c|}
\hline 5. & Bâbî Efendi & 2 manzume, vr. $23^{\mathrm{b}}, 24^{\mathrm{b}}$ \\
\hline 6. & Bâkî & 1 manzume, vr. $12^{\mathrm{b}}$ \\
\hline 7. & Bedrî & 1 manzume, vr. $39^{\mathrm{a}}$ \\
\hline 8. & Cevherî & 1 manzume, vr. $18^{\mathrm{a}}$ \\
\hline 9. & Dervîş Ahmed & 1 manzume, vr. $11^{\mathrm{a}}$ \\
\hline 10. & Emnî & 2 manzume, vr. $10^{\mathrm{b}}, 23^{\mathrm{a}}$ \\
\hline 11. & Enîs Receb Efendi ${ }^{9}$ & 1 manzume, vr. $27^{\mathrm{b}}$ \\
\hline 12. & Esâmeci Hüseyn & 1 manzume, vr. $15^{\mathrm{a}}$ \\
\hline 13. & Fahrî & 1 manzume, vr. $4^{\mathrm{a}}$ \\
\hline 14. & Fakîrî Çelebi & 2 manzume, vr. $34^{\mathrm{a}}$ \\
\hline 15. & Fennî Çelebi & 2 manzume, vr. $6^{\mathrm{b}}, 14^{\mathrm{a}}$ \\
\hline 16. & Fethî & 1 manzume, vr. $9^{\mathrm{b}}$ \\
\hline 17. & Füyûzî Mehemmed Efendi10 & 1 manzume, vr. $17^{\mathrm{b}}$ \\
\hline 18. & Halîl ${ }^{11}$ & 1 manzume, vr. $21^{\mathrm{a}}$ \\
\hline 19. & Hasîb Çelebi & 1 manzume, vr. $27^{\mathrm{a}}$ \\
\hline 20. & Havfî Çelebi & 1 manzume, vr. $44^{\mathrm{b}}$ \\
\hline 21. & Hitâmî & 1 manzume, vr. $19^{\mathrm{a}}$ \\
\hline 22. & Hicrî & 1 manzume, vr. $7^{\mathrm{a}}$ \\
\hline 23. & Himmet-zâde Abdullâh Efendi ${ }^{12}$ & 1 manzume, vr. $25^{\mathrm{a}}$ \\
\hline 24. & Huldî Çelebi & 1 manzume, vr. $21^{\mathrm{b}}$ \\
\hline 25. & İbrâhîm Efendi & 1 manzume, vr. $41^{\mathrm{a}}$ \\
\hline 26. & İlmî Efendi & 1 manzume, vr. $30^{\mathrm{b}}$ \\
\hline 27. & İmâm-zâde Şükûfí Mehemmed & 1 manzume, vr. $14^{\mathrm{b}}$ \\
\hline 28. & İzzetî Çelebi & 1 manzume, vr. $31^{\mathrm{a}}$ \\
\hline 29. & Külâhî & 1 manzume, vr. $17^{\mathrm{a}}$ \\
\hline 30. & La'lî & 1 manzume, vr. $15^{\mathrm{a}}$ \\
\hline 31. & Lutfî & 2 manzume, vr. $22^{\mathrm{b}}$ \\
\hline
\end{tabular}

9 Asıl adı Receb olan şair, Edirne'de doğmuştur. Gülşenî tarikatına mensup Dervîş Halîl adlı birinin oğludur. Seyyid Muhammed Ârif Dede’nin ölümü üzerine 1095/1683 yllında Edirne Mevlevihanesi şeyhliğine getirilmiş ve altmış sene burada seyhlik yapmıstır. Vefat tarihini Fatin, Semseddîn Sâmî, Mehmed Süreyyâ,, Esrâr Dede 1147/1734; Bursalı Mehmed Tâhir 1145/1732; Râmiz, Nâil Tuman ve Mecelle 1146/1733 olarak gösterirler (Önkaş, A. Nilgün 2013). Enîs Receb Dede Dîvânı yüksek lisans tezi olarak çalışılmıştır (Ceyhan, Âdem 1990). Mecmuada yer alan manzume şairin Dîvân'ında bulunmamaktadır.

10 Asıl adı Mehmed'dir. Mehmed Füyûzî Efendi olarak tanındı. Medrese öğrenimi görerek mülâzım oldu. Müderrislik yaptı. Rikab-ı Hümayun kaymakamı Bıyıklı Mustafa Pasa'ya intisap ederek 1103/1692'de Sakız kadılı̆̆ına atandı. 1106/1695'te Diyarbakır kadısı oldu. 1115/1703’te Devrakanî, Dikrin ve Gökçedağ kazaları, 1123/1711'de de Dodurga kazası arpalık olarak verildi. 1135/1723'te vefat etti (Kesik, Beyhan 2014).

11 Tuhfe-i Nâilı’’de Halîl mahlasını kullanan ve kadı olduğu belirtilen tek sair yer almaktadır. Buna göre Halîl Efendi "Kadı Halîl” olarak bilinmektedir ve Elmalılıdır (Kurnaz ve Tatcı 2001: 257). Şair hakkında bunun dışında herhangi bir bilgi bulunmamaktadır.

12 Şeyh Abdullah Efendi adıyla da bilinen Himmet-zâde Abdî, Bayrâmiyye tarikatı şeyhlerinden Himmet Efendi’nin oğludur. Himmet-zâde Abdî, 1050/1640 tarihinde İstanbul'da doğdu. Edebiyatımızda Abdî mahlasıyla başka şairler de eser verdiği için o, babasından dolayı Himmet-zâde adıyla anılır. Siirlerinde Himmet-zâde, Abdullah, Dervis Abdullah gibi mahlasları kullansa da onun en çok kullandığı ve şöhret kazandığı mahlası Abdî'dir. Abdî’nin asıl mesleği vaizliktir. 1694’te Fatih Camii vaizliği görevine getirildi. Bu görevdeyken Sultan II. Mustafa'nın 1109/1697'daki Avusturya seferine ordu vaizi göreviyle katıldı. Ömrünün son demlerinde Beyazıt Camii ve Süleymaniye Camii vaizliği görevlerini yapan Himmet-zâde Abdî, 1122/1710 tarihinde vefat etti (Bayram, Ömer 2013). Himmet-zâde Abdî Dîvânı mezuniyet tezi olarak çalışılmıştır (Bayram, Ömer 1997). Mecmuada yer alan manzume şairin Dîvân'ında bulunmamaktadır.

Adres

Kurklareli Üniversitesi, Fen Edebiyat Fakültesi, Türk Dili ve Edebiyat Bölümü, Kayalı Kampüsü-Kırklareli/TÜRKIYYE e-posta: editor@rumelide.com
Adress

Kırklareli University, Faculty of Arts and Sciences, Department of Turkish Language and Literature, Kayalı Campus-Kırklareli/TURKEY e-mail: editor@rumelide.com 


\begin{tabular}{|c|c|c|}
\hline 32. & Mâhir Abdullâh Efendi¹3 & 3 manzume, vr. $24^{\mathrm{b}}, 28^{\mathrm{b}}, 35^{\mathrm{a}}$ \\
\hline 33. & Mahmûd Hayrabolı & 4 manzume, vr. $7^{\mathrm{a}}, 9^{\mathrm{b}}$ \\
\hline 34 . & Mahmûd Kânkırî & 1 manzume, vr. $14^{\mathrm{a}}$ \\
\hline 35 . & Mehemmed el-Yanyevî & 1 manzume, vr. $17^{\mathrm{b}}$ \\
\hline 36. & Mehemmed Şeyhî Mevlevî & 2 manzume, vr. $29^{a}$ \\
\hline 37. & $\begin{array}{c}\text { Mehemmed Kethudâ-yı Mehterân-ı Hayme-i } \\
\text { Hassa }\end{array}$ & 1 manzume, vr. $15^{\mathrm{a}}$ \\
\hline 38. & Ma'nevî14 & 2 manzume, vr. $17^{\mathrm{a}}$ \\
\hline 39. & Medhî & 1 manzume, vr. $33^{\mathrm{b}}$ \\
\hline 40. & Mehemmed Vehbî & 1 manzume, vr. $6^{\mathrm{b}}$ \\
\hline 41. & Mukîm & 2 manzume, vr. $42^{\mathrm{b}}, 3^{\mathrm{a}}$ \\
\hline 42. & Mustafâ Efendi & 2 manzume, vr. $4^{\mathrm{b}}, 16^{\mathrm{a}}$ \\
\hline 43. & Müezzîn Abdullâh Çelebi & 2 manzume, vr. $6^{\mathrm{a}}, 12^{\mathrm{a}}$ \\
\hline 44. & Müstakîm Çelebi15 & 1 manzume, vr. $14^{\mathrm{b}}$ \\
\hline 45 . & Müftî Efendi & 1 manzume, vr. $22^{\mathrm{b}}$ \\
\hline 46. & Nahîfî Çelebi ${ }^{16}$ & 3 manzume, vr. $35^{\mathrm{a}}, 38^{\mathrm{b}}, 39^{\mathrm{a}}$ \\
\hline 47. & Na'îmî & 1 manzume, vr. $40^{\mathrm{a}}$ \\
\hline 48. & Nakşî İbrahîm Efendi' ${ }^{17}$ & 2 manzume, vr. $13^{\mathrm{b}}$ \\
\hline
\end{tabular}

Bosna'da doğmuş olmasına rağmen Antep’e büyük hizmetleri olmuştur. Sultan II. Mustafa dönemi şairlerindendir. Mâhir tahsilini bitirdikten sonra 1091/1651 yllında İstanbul'a gelmis, 1106/1693'te İvaz Efendi Medresesi'nde müderris olmuştur. 1106/1694'de Şahkulu Medresesi'ne geçmiştir. 1107/1695'de ise Molla Gürânî Medresesi'nde müderris olmuştur. Mahir Efendi, II. Mustafa'ya takdim ettiği kaside ve medhiyelerle göze girerek kısa zamanda yükselmiștir. Mâhir Efendi, 1122/1710'de, Beliğ'e göre ise (Abdülkadiroğlu, 1999:373) 1121/1709-1710 yllında Antep’te 63 yaşında iken vefat etmiştir. Dîvân'ının içinde teşekkürnâme adlı bir eseri vardır. Müseddes nazım şekliyle Sultan II. Mustafa'nın cülusunun anlatıldı̆̆ manzume 30 bentten meydana gelmektedir (Yakar, H. İbrahim 2014).

14 Kaynaklarda bu yüzyılda yaşadığı belirtilen Ma'nevî mahlaslı tek şair bulunmaktadır. Bolu çevresinden ve şehrî/İstanbullu olduğu ifade edilmişse de Mustafa Ma‘nevînnin doğum yeri ve tarihi hakkında kesin bir bilgi yoktur. 1691 senesinde Kadırga'daki Sokullu Mehmed Paşa zâviyesine şeyh ve aynı tarihlerde Bahçekapıda'ki Valide Sultan Câmii'ne vâiz olarak tayin olunmuştur. 1104/1692'de 2. Ahmed’in seçimiyle Edirne’ye çağrılarak Ordû-yı Hümâyûn şeyhliğine tayin olunan Ma'nevî, 1114/1702 tarihinde vefat etmiștir. 1698 senesinde gerçekleșen barıșa her mısrası bir tarih olmak üzere 110 mısralı bir kaside yazıp asrın veziriazamı Amcazâde Hüseyin Paşa'ya takdim etmiștir (Mermer, Kenan 2013).

15 İstanbul'da doğan Müstakîm'in asıl adı Mehmed'dir. Gençliğinde Halvetîye şeyhi Ümmî Sinânzâde Hasan Efendi'ye intisap ettikten sonra İstanbul Aksaray'da Sofular Mahallesi'ndeki Halvetîye Alaaddin Zaviyesi'ne seyh oldu. 1105/169394 yllındaki büyük yangında tekke yanınca, bir süre Ebu Eyüp Ensârî Camii’nde hasırların üstünde yaşadı. Defterdar Hasan Pașa, Sofular Tekkesi'ni tekrar inşa edince kendi tekkesinde ibadetle meşgul oldu. Vefat tarihi Sâlim'de 1120/170809; Safâyî, Belîğ ve Sicill-i Osmânî’de 1121/1709-10 olarak gösterilmektedir. Sesinin güzelliği ile tanınan Müstakîm, devrinde hoşsohbet bir insan olarak tanındı. Bu özelliği ile zamanının ileri gelenlerinin meclislerinde bulundu. Ayrıca tarih düsürmede yeteneği olan sairin evinin duvarlarını beyitlerle süslediği rivayet edilir (Aksoyak, İ. Hakkı 2013). Mecmuada Müstakîm Çelebi'ye ait olan şiirin dördüncü beytinde yer alan "Sem"-i sultâna irince çünki bu müjde didüm/Hâne-kâhum yapmak ile behre-yâb eyle bizi” ibaresinden şiirin bu zata ait olduğu tahmin edilebilir.

16 Asıl adı Süleyman'dır. İstanbul'da dünyaya geldi. Doğum yllı 1076/1665-66 olarak tahmin olunmaktadır. Bir taraftan hattatlık yaparken öte yandan memuriyet hizmetinde bulundu ve Dergâh-1 Âli yeniçeri halifelerinden oldu. 1094/1683'de memuriyetle Mısı'a gitti. Bir görüse göre Mısır’a giderken, bir görüse göre ise Mısır yoluyla hacdan dönerken Konya'da Mevlevîliğe intisap etti. 1100/1688-89'da İran'a elçi tayin edilen Ebukavuk Mehmed Paşa'nın kâtibi olarak İran'a gitti. 1131/1718-19'da Macaristan elçisi İbrahim Ağa maiyetinde Pasarofça Antlaşması için bu ülkeye gitti. Dönüşünde hizmetinden dolayı Divan-ı Sultanî hocalıklarından başmukataacılığa getirildi. 1138/1725-26'da şıkk-ı sânî defterdarı olan Nahîfi bir süre sonra emekli oldu ve bir daha memuriyet almadı. 1151/1738'de İstanbul'da vefat etti (Karavelioğlu, M. Ali 2014). Nahifi Dîvânı doktora tezi olarak çalışılmıştır (Aypay, İrfan 1992). Mecmuada bulunan şaire ait üç manzumenin ikisi Dîvân'inda yer alırken biri Dîvân'da bulunmamaktadır.

17 Asıl adı İbrahim'dir. İstanbul'da, 1051/1640 senesinde dünyaya gelmiştir. Vüzeradan Deli Hüseyin Paşa'nın kethudası Mehmed Ağa'nın mahdumudur (Ekinci 2018: 2233). İlk tahsili döneminde hayatı boyunca İstanbul'un çesitli camilerinde vaazlarda bulunabilmesine temel olacak bilgileri edinmiş, daha sonra kendisini zahirî ve bâtıni ilimlerde yetiştirmiş ve çevresinde değerli bir zat olarak tanınmıştır. Halvetîye tarikatına mensuptur. Nakşî İbrahim Efendi Şehzade Camii'nde vaiz olarak vazifeli bulunduğu sırada 1114/1702 tarihinde vefat etmiştir. Nakşî Dîvânı yüksek lisans tezi olarak çalıșlmıştır (Ayhan, Emrah 2000). Mecmuada şaire ait Sakız Adası'nın fethi ve II. Mustafa'nın cülusu için düşürdüğü iki tarih Dîvân'inda yer almaktadır.

Adres
Adress

Kırklareli University, Faculty of Arts and Sciences, Department of Turkish Language and Literature, Kayalı Campus-Kırklareli/TURKEY e-mail: editor@rumelide.com 


\begin{tabular}{|c|c|c|}
\hline 49. & Nâzî Çelebi & 1 manzume, vr. $26^{b}$ \\
\hline 50. & Nazîm ${ }^{18}$ & 2 manzume, vr. $15^{\mathrm{b}}, 16^{\mathrm{a}}$ \\
\hline 51. & Nâzım Çelebi & 2 manzume, vr. $5^{\mathrm{a}}, 20^{\mathrm{b}}$ \\
\hline 52. & Nazmî İbrâhim Efendi & 1 manzume, vr. $6^{\mathrm{a}}$ \\
\hline 53. & Osmân Efendi & 1 manzume, vr. $5^{\mathrm{b}}$ \\
\hline 54. & Rahîmî & 1 manzume, vr. $11^{\mathrm{b}}$ \\
\hline 55. & Remzî̀19 & 3 manzume, vr. $31^{\mathrm{b}}, 32^{\mathrm{a}}$ \\
\hline 56. & Sâbit ${ }^{20}$ & 1 manzume, vr. $25^{\mathrm{b}}$ \\
\hline 57. & Süleymân el-Müderris & 3 manzume, vr. $7^{\mathrm{b}}, 8^{\mathrm{a}}, 8^{\mathrm{b}}$ \\
\hline 58. & Sürûrî & 1 manzume, vr. $10^{b}$ \\
\hline 59. & Şâhîn Girây & 1 manzume, vr. $44^{\mathrm{b}}$ \\
\hline 60. & Şekûrî & 2 manzume, vr. $1^{\mathrm{b}}$ \\
\hline 61. & Tablî Efendi & 1 manzume, vr. $27^{\mathrm{b}}$ \\
\hline 62. & Tâlib ${ }^{21}$ & 2 manzume, vr. $26^{\mathrm{a}}$ \\
\hline 63. & Tophâneli Mehemmed Efendi & 2 manzume, vr. $29^{b}, 6^{b}$ \\
\hline 64. & Vahyi $\hat{i}^{22}$ & 2 manzume, vr. $15^{\mathrm{b}}, 25^{\mathrm{a}}$ \\
\hline 65. & Vâlî Efendi & 1 manzume, vr. $30^{\mathrm{a}}$ \\
\hline 66. & Zamîrî & 1 manzume, vr. $13^{\mathrm{a}}$ \\
\hline 67. & Zülâlî Çelebi ${ }^{23}$ & 2 manzume, vr. $32^{\mathrm{b}}, 33^{\mathrm{b}}$ \\
\hline 68. & Mahlassiz & 3 manzume, vr. $21^{\mathrm{a}}, 28^{\mathrm{a}}, 39^{\mathrm{a}}$ \\
\hline
\end{tabular}

18 Asıl ismi Yahya'dır. İlk olarak "Halîm" mahlasını kullanırken Neşâtî tarafından kendisine "Nazîm" mahlası verildi. İstanbul'da doğdu. Esad Efendi'ye göre doğduğu semt Kumkapı, Tayyarzâde Ata Bey'e göre ise Kasımpaşa'dır. Doğum yılı bilinmemektedir. Kaynaklarda vefat ettiğinde seksen yasına yakın olduğunun söylenilmesi ve bazı kaynaklarda ölüm tarihinin 1139/1727 olarak belirtilmesi 1060-1061/1650-1651 senelerinde doğduğunu göstermektedir. IV. Mehmed döneminde şiir ve musikiye olan kabiliyeti sebebiyle Enderun'a alınd. Burada iyi bir tahsil görüp Arapça ve Farsça öğrendi. Kilâr-ı hassada nevbetçi başı iken bazarbaşılık vazifesi ile mükafatlandırıldı. Sicill-i Osmânîye göre ise "kuruyemişci başı" oldu. Hayatının sonuna kadar bu görevde kaldı. 1139/1727 tarihinde Edirne'de vefat etti (Gümüş, Nevin 2014). Yahya Nazîm Dîvânı doktora tezi olarak çalışılmıștır (Çakır, Mustafa S. 2018). Mecmuada yer alan şaire ait iki manzumeden biri Dîvân'da yer alırken diğeri Dîvân'da mevcut değildir.

19 Asıl adı Mehmed olan şair, İstanbul'da doğmuştur. Kuranı hıfz ettiği için Hafız Mehmed Efendi olarak da anılmıştır. Kaynaklarda hayatı hakkında çok bilgi bulunmamaktadır. Asrın şairlerinden olup tarih söylemekde başarılıdır. II. Mustafa'nın 1106/1694-95 tarihinde tahta çıkışına "Hümâyûn ola hatth pâdişâhın" dizesiyle tarih düşürmüştür (Altuner 1989: 186-87; İnce 2018: 232-33). Tezkirelerde yer alan bu tarih mecmuada da yer almaktadır.

20 Meşhur şair, Bosnalı Alâaddin Sâbit'tir. Mecmuada yer alan manzumesi şairin Dîvân'ında "Berây-ı Cülûs-ı Mustafa Hân" başlı̆̆ ile s. 319-20'de yer almaktadır (Karacan, Turgut 1991).

$21 \quad$ Kaynakların hayatı ile ilgili farklı bilgiler verdikleri sairin asıl adı Mehmed Tâlib’tir. Ali Emirî doğum yerini Diyarbakır, Belîğ ve Mehmed Sirâceddin Bursa olarak gösterir. 1097/1686'da Bursa'da Arabiyye medresesine hâric payesiyle atanmış, 1109/1698'de sahn itibariyle Müftü Ahmed Paşa medresesine nakledilmiş, 1111/1699'da Molla Hüsrev Medresesi'ne müderris olmuş, 1114/1702'de Kütahya kadılığına atanmıştır. Şeyhülislam Başmakçızâde Ali tarafından 1117/1705'te Erzurum kadısı olarak atanmıştır. Tâlib, bu görevdeyken 1118/1706'da vefat etmiştir (Tuğluk, H. İbrahim 2014). Tâlib Dîvânı yüksek lisans tezi olarak çalışılmıștır (Erdem, Melike 1994). Şairin mecmuada bulunan iki manzumesi de Dîvân'inda yer almaktadır.

22 İstanbul'da doğdu. Asıl adı Mehmed'dir. Şeyh Seyyid Mehmed Vahyî Efendi olarak tanındı. Şeyhülharem Tekkesi’nde șyhlik yapt. 1125/1713’te Zâkirzâde Seyh Abdullah Efendi yerine Tophane Kılıç Ali Paşa Camii vaizliğine getirildi. Sonra 1127/1715'te Arapzâde Hasan Efendi yerine Eyüp Sultan ve 1128/1716'da Sultan Selim camilerine vaiz olarak atandı. Bu görevde iken 1130/1718'de vefat etti (Kesik, Beyhan 2014). Şairin Dîvân'ı yayımlanmıştır (Taş, Hakan 2017). Mecmuada yer alan iki manzumesinden biri Dîvân'inda yer almaktadır.

$23 \quad$ Tezkirelerde ve biyografik kaynaklarda bu yüzyılda yaşadığı söylenen ve Zülâlî mahlasını kullanan tek şair vardır. Bu da Deli Hüseyin Paşa Silahdarı Ali Ağa'nın oğlu Enderunlu Hasan Zülâlî Efendi'dir. Asıl adı Hasan'dır. Aydonat’ta doğdu. 1099/1687-88'de öğrenimini tamamlayıp Şeyhülislâm Seyyid Feyzullâh Efendi'den mülazım oldu. Galatasaray Medresesi ve Süleymaniye Medresesi’nde müderrislik yaptı. 1131/1718-19 yılında Bursa kadısı, 1141/1729'da İstanbul kadısı oldu. 1143/1730'da Anadolu kazaskerliğine atandı. 1144/1731-32'de azledilerek Resmo’ya sürüldü. Aynı yll vefat etti (Bülbül, Tuncay 2014). Mecmuada yer alan manzume Enderunlu Hasan Zülâlîye ait olabileceği gibi bu yüzyllda yaşayan ve Zülâlî mahlasını kullanan başka bir şaire de ait olabilir.

Adres

Kırklareli Üniversitesi, Fen Edebiyat Fakültesi, Türk Dili ve Edebiyatı Bölümü, Kayalı Kampüsü-Kırklareli/TÜRKİYE e-posta: editor@rumelide.com
Adress

Kırklareli University, Faculty of Arts and Sciences, Department of Turkish Language and Literature, Kayalı Campus-Kırklareli/TURKEY e-mail: editor@rumelide.com 


\begin{tabular}{|c|c|c|}
\hline & Toplam & 100 \\
\hline
\end{tabular}

\section{Mecmuanın muhteva özellikleri}

Mecmuada muhteva itibarıyla Sultan II. Mustafa'nın cülûsu ve Sakız Adası'nın fethi ile ilgili manzumeler yer almaktadır. Bunun dışında Remzî mahlaslı bir şair tarafından padişahın hatt-ı hümayunu ile ilgili bir tarih kıt'ası, Nazîm mahlaslı bir şair tarafından Valide Sultan'ın Edirne’ye gelişi için yazılmış olan Edirne redifli bir kıt‘a, Cevherî mahlaslı bir şair tarafından mesnevi nazım şekliyle yazılmış 79 beyitlik bir arz-ı hâl yer almaktadır.

\subsection{Sakız Adası'nın fethi ile ilgili manzumeler}

Sakız Adası, Ege Denizi’nin beşinci büyük adası durumundadır. Osmanlı Devleti tarafından fethedilmeden önce Cenevizlilerin kontrolünde bulunan ada, 1566'da Kaptanıderya Piyâle Paşa tarafından çatışma olmaksızın zaptedildi. Sakız adası, 1694 yılında meydana gelen kısa süreli Venedik işgaline kadar Kaptanpaşa eyaletindeki idarî durumunu korudu. Venedikliler 1694'te papalık, Floransa ve Malta donanmalarının da yardımlarıyla Sakız'ı kuşattı ve 21 Eylül'de ada, Antonio Zeno'ya teslim edildi. Adadaki müslüman nüfus Venedik gemileriyle üç gün içerisinde boşaltılarak Anadolu sahiline nakledildi. Ancak Osmanlı filosunun karşı harekâtı sonucu 22 Şubat 1695'te adaya asker çıkarıldı ve kale kolayca alındı. Bu tarihten, adanın 1913 yılında Yunanlılar tarafından işgal edilmesine kadar birkaç kuşatma girişimi sayılmazsa ada, Osmanlıların hâkimiyetinde kaldı (Örenç 2009: 6-10).

Sultan II. Mustafa'nın tahta çıkışının ilk haftasında (Çibir 2016: 21) gerçekleşen Sakız Adası'nın fethi, mecmuada birçok şair tarafından konu edilmiş ve bu fethe tarih düşürülmüştür. ${ }^{24}$

Mecmuada; Mahmûd Hayrabolu, Mahmûd Kânkıri, Müstakîm Çelebi, Nâzım, Emnî Efendi, Tâlib, Hasîb Çelebi, Tablî Efendi, Mehemmed Şeyhî Mevlevî, Vâlî Efendi, İlmî Efendi, Remzî, Fakîrî, Medhî ve başlı̆̆ında "Du'â-gûy" yazan fakat mahlası bulunmayan bir şair tarafından Sakız'ın fethi ile ilgili tarih manzumeleri kaleme alınmıştır.

Mecmuada Sakız’n fethedilmesi “düşmanın ağzından sakızın düşmesi, sakızın düşmanın elinden alınması, din düşmanlarına sakızı çiğnetmemek, düşmanın ağzından sakızı kapmak, sakızın İslam’ın temiz ağzına nasip olması, sakızın alınıp düşmanın ayaklar altında çiğnenmesi” gibi kinayeli anlatımlarla konu olmuştur. Bu kullanımlardan bazıları örnek oluşturması hasebiyle aşağıda gösterilmiştir.

Deniz üzerindeki kâfir donanması bozulmuş ve Sakız feth olunup düşman ayaklar altında çiğnenmiştir:

Bozuldı țōbdan bahr üzre küffāruñ donanması

Saḳız fetḥ olınup çignendi pā-māl oldı hep ac dā ～(Remzî, vr. 32a-b)

Allah’ın yardımı imdada yetişmiş ve Sakız yeniden İslam’ın temiz ağzına nasip olmuştur:

Biḥamdi'llāh olup imdādı bād-1 'avn-i Yezdānuñ

Yine Saḳız dehān-ı pāk-i İslāma nașīb oldı

(Tâlib, vr. 26a-b)

24

Sakız Adası'nın fethinin klasik Türk edebiyatına nasıl yansıdığına dair bkz. Kaplan, H. (2018). "Divan Edebiyatında Sakız ve Sakız’n Fethinin Edebiyatın Nükte Dünyasına Yansımaları”. Ekev Akademi Dergisi, 73, 367-394. 
Vahşi bir köpek gibi gururla "Sakız’ çiğnerim!" diyen Avrupalıların korkusundan ağzındaki Sakız düşmüştür:

Dehşetinden düşdi efrencüñ dehānından Saḳız

Çignerüm dirken ġurūr ile o kelb-i žù-ḍarūs

(Mahmûd, vr. 9b-10b)

II. Mustafa mecmuada yer alan manzumelerde tahta çıkışının fethe uğurlu gelmesi ile konu edilmiştir. Aşağıdaki beyitte Tablî Efendi, II. Mustafa'nın gelişinin kutlu ve mübarek olduğunun Sakız’n alınmasından belli olduğunu dile getirmiştir:

Maḳdemi sa' d u mübārek olduġı günden `ayān

Saḳız alındı vü ḳatl oldı gürūh-ı eşḳıyā

Remzî, Sultan Mustafa’nın ayağının uğurlu olduğunu ve bunun ardından Allah’ın bu zaferi verdiğini dile getirmektedir:

Olup yümn-i ḳudūm-1 Muștafầ Huān der-' aḳab pey-rev

Cülūs eșnālarında itdi Ḥaḳ bu nuṣreti ic țā

(vr. 32a-b)

Tâlib ise aşağıda yer alan beyitinde heybetli padişahın gelişinin uğuruyla bu zaferin vuku bulduğunu dile getirmektedir:

Bu nușret bir şehüñ 'așrında vāḳı ${ }^{`}$ olmadı bā' is

Beli yümn-i ḳudūm-i pāk-i Sulțān-1 mühīb oldı

(vr. 26a-b)

\subsection{Sultan II. Mustafa'nın tahta çıkıșı ile ilgili manzumeler}

Şehzade II. Mustafa, amcası II. Ahmed Han 6 Şubat 1695 günü vefat ettiğinde onun yerine tahta çıkmak üzere hiç kimseye boyun eğmeden, bir bildiri yayınlamadan ve beklemeden; yaşamakta olduğu Edirne Sarayı veliaht dairesinden çıkıp taht odasına girmiş ve tahta kurulmuştur. Devletin ileri gelenlerini padişah sıfatıyla nezdine getirtip, onlardan hem biat almış hem de ülke işlerini müzakereye başlamıştır. Sultan II. Mustafa, tahta çıkışının üçüncü günü bir hatt-ı hümayun yayımlamış ve "bizzat ordunun başına geçip seferlere katılacağını; din-i İslam uğruna vücudunu feda edeceğini, gerektiğinde kuru ekmek yiyip halkına hizmet edeceğini” bildirmiştir (Çibir 2016: 7-17).

Mecmuada Sultan II. Mustafa'nın cülûsu için kaleme alınan manzumelerde; padişahın tahta çıkması, devlet erkanının karşısına dizilip ona biat etmesi, II. Mustafa'nın gazaya niyet etmesi, hatt-ı hümayun yayımlaması, kafirden intikam almak istemesi, keskin kılıcını düşmalarının üzerine çekmesi gibi olaylar tasvir edilmiştir.

Nazmî İbrâhîm Efendi, Sultan Mustafa'nın cülûsuna tarih düşürmek için kaleme aldığı 5 beyitlik kıt'asında padişahın kaygısızca tahta geçişini ve devlet erbabının padişahın karşısına dizilip ona biat etmelerini şu şekilde tasvir eder:

Bașup țaşra ḳudūmın künc-i vaḥdetde sa‘ ādetle

Cülūs itdi geçüp Ḩān Muștafā taḩıına bì-ḳagg̀u

Olındı dest-būs tecdìd-i bì at eyleyüp cümle

Dizildi ṣaḥnına erbāb-1 devlet sū-be-sū ḳarşu

(vr. 6a-b) 
Aşağıdaki beyitlerde ise Hayrabolulu Mahmûd, tahta geçer geçmez gazaya niyet eden padişahın ilk olarak savaş için gerekli olan mühimmata özen gösterdiğini, askerleri arasından tüfek atıcı olanları seçip hazırlanmalarını emrettiğini ve kendisinin de hazırlanarak kafirden intikam almayı murat ettiğini dile getirir:

Evvelā idüp mühimmāt-1 gazāya ihtimām

Re'y-i ṣā 'ib eyledi hakḳ̂ā ki ol pākīze-tūs

Gördi istīlā-yı küffār 'ālemi ḳılmış ḩarāb

Cümle erbāb-1 düvel olmış nizāāmında ye 'ūs

Dīn ü devlet gàaretinden ol şecíc -i nām-dār

Emr idüp techīz ceyşe giydi ol sā' at lebūs

'Askerinden intihāb idüp tüfeng-endāzlar

Düşmen-i dīn içün i' dād itdi şemşīi fü 'ùs

Didi gelsün vaḳt-i ġayretdür baña ḳulum diyen

Baş u cāna ḳalmayup dìn uğrına olsun ḩabūs

İntiḳām almaḳ murādumdur bugün küffārdan

Eșsalāya ehl-i ỉmān eșșalā çalındı kūs

(vr. 9b-10b)

Çok iyi hocalardan ders alan II. Mustafa, devlet idaresini ve harp oyunlarını çok iyi bir şekilde öğrenmiştir. Ok atmada mahir ve iyi bir silahşör olan II. Mustafa, yalandan nefret eder ve doğruları ödüllendirirdi (Çibir 2016: 13). Mecmuada yer alan manzumelerde II. Mustafa'nın bu özelliklerine de yer verilmiştir.

Dervîş Ahmed 31 beyitlik kasidesinde II. Mustafa'nın hünerlerini sıraladıktan sonra onu, Rüstem ve Sâm ile kiyaslayarak onlardan üstün tutmuştur:

Yā cirìd atsuñ eger ḳuvvet ile destinden

Tibr gibi eylemede țayy-1 hezārān meydān

Seni at üzre eger görse silāḩ̧̧̋̈r-i felek

[Bakssa] cevlān-1 semendine ḳalurdı ḥayrān

Yā kemān-keşliginin ey husrev-i heft-kişver

Kuvvet-i nāṭ̂ḳa yitmez ki idem şerḥ ü beyān

Var mı bir merd-i tîr-endāz ḳatı zūr-bāz

Ki çeke sencileyin saḥt-1 dilïrāne kemān

Çekemez çekdügünüz yāy şehā Rüstem ü Sām

Bir kepāze olımaz saña kemān u destān

Yazdugın hatț-1 hümāyūn[a] felek hayretde

Dāniş-i re 'y-i müníine cihān ser-gerdān

(vr. 11a) 
Yine İmâmzâde Şükûfî Mehmed, padişahın cülûsuna tarih düşürdüğü beş beyitlik manzumesinde düşmandan intikam almak için daima şevkle hazır bulunan padişahın savaşta, ok atmakta ve kılıç vurmakta yetenekli olduğunu dile getirmiştir:

'Adūsından kemāliyle murādı intiḳām almaḳ

Dem-ā-dem şevk ile zāàtı bilüñ āmāde vü hạāı̀r

Ma'ārifle vücūd-ı pāki pür-zìver hușūusā kim

Ġazā 'ilminde tìr atmaḳda seyf urmaḳda hep māhir ～(vr. 14b-15a)

Vâlî Efendi ise cihan akıllısı olan padişahın asla yalana itibar etmeyeceğini ve bundan dolayı ona kimsenin hile yapamayacağını dile getirir:

O huşyār-1 cihān itmez dürūğa i' tibār aṣlā

Anuñçün idemez kimse tekellümde aña nireng (vr. 30a-b)

Mecmuada yer alan manzumeler II. Mustafa'nın cülûsunun halk tarafından nasıl karşılandığı ve yapılan merasimler ile ilgili de bilgiler vermektedir. Padişah tahta çıktıktan sonra kûs-ı şâhîler çalınarak halka II. Mustafa'nın cülus haberi müjdelenmiştir. Hâl ehli olanlar el öpüp padişaha bağlanmışlardır. Halk hayır duası etmiş ve kutlamak için gül-bânglar okunup yâ-hûlar çekilmiştir. Padişah adına hutbe okunmuş, tuğra çekilmiş ve sikke basılmıştır.

Çalındı kūs-1 şāhi oldı peydā bir sürūr-ı nev

Ki tebşīi itdiler halḳa cülūs-1 Muștafā Huānı

Çekdiler gül-bāng yā-hū hep mübārek-bād içün

Cümle ‘ālem halḳı ol dem eyleyüp hayr du'à

(Füyûzî, vr. 17-19a)

Ya'nī Sulțān Muṣtafā ibn Meḥemmed Hֵāndan

$B \bar{i}^{\prime}$ at itdi ehl-i hall u 'aḳd idüp dest-būs

İsmine oḳındı huțbe mülket-i ‘ Oșmānda

Nāmına ṭugrā çekildi yazdı kātibler rü’ūs

Sikkesi ḳazıldı ḥālā dirhem ü dīnārda

Ṭoldı ‘ālem cevher ile ḳaldı rag̈betden fülūs

(Mahmûd, vr. 9b)

Sultan II. Mustafa tahta çıktığında Osmanlı Devleti, on iki seneden beri Avusturya, Lehistan, Rusya ve Venediklilerle harp hâlinde idi (Çibir 2016: 14). Halk uzun süren savaşlar ve mağlubiyetlerle yıpranmış bir haldeyken Sultan II. Mustafa'nın tahta çıkmasıyla yeniden ümitler yeşermiştir. Toplumun içinde bulunduğu bu ruh halini ve padişahın cülûsunun nasıl karşılandığını mecmuada yer alan beyitlerden açıça çıkarmak mümkündür.

Aşağıdaki beyitte Füyûzî Mehmed Efendi halk, din ve devlet zulüm ile dolmuşken II. Mustafa'nın zafer kılıcını çıkarıp dünyaya ışık verdiğini dile getirir.

Ḩalḳ-1 ‘ālem dīn ü devlet ẓulm ile țolmış iken

Seyf-i nușret ile açup 'āleme virdi żiyā

(vr. 17a-19a) 
Tablî Efendi, Sultan II. Mustafa'nın tahta çlkmasıyla zulüm ve rüşvet kapılarının kapandığını müjdelemektedir:

Devlet ile taht-1 ' ālì-bahtına ḳıldı cülūs

Müjde ey dil kim ḳapandı bāb-ı zulm ü irtişā

(vr. 27b)

Sultan II. Mustafa, IV. Murad'dan sonra gelen Osmanlı padişahları içinde en liyakatlisi, en âlimi ve en kültürlüsü idi (Çibir 2016: 13). Aşağıdaki beyitte Mâhir Abdullâh Efendi, çok zamandır irfan ehli olan kimselerin ayaklar altında kaldığını ancak II. Mustafa'nın cülûsu ile artık liyakat erbablarının vakti olduğunu dile getirir:

Nice demdür olmış idi pāy-māl ehl-i kemāl

Çarha nāz eylerse erbāb-1 liyāḳat vaḳtidür

(vr. 28b-33b)

Nâzî Çelebi ise çok zamandır harap bir vaziyette olan cihanın Sultan II. Mustafa'nın cülûsu ile yeniden mamur hale geldiğini dile getirmektedir:

Çok zamān idi harāāb olmuşdı ețāâ-1 cihān

Hak Te āāā yeñiden dünyāyı ma' mūr eyledi

(vr. 26b-27a)

Mecmuada yer alan manzumelerde Sultan II. Mustafa, "Kahramân-ı zamân, İskender-i sânî, zıll-ı Yezdân, sultân-ı bahr ü ber, Süleymân-rütbet, Rüstem-şecâ'at, Husrev-i heft-iklim, Cem-satvet, Süleymân-haşmet, ma'delet-i Nuşirevân, Ömer-'adl, Alî-sîret, Rüstem-heybet, şehen-şâh-ı serir-i ma'delet, Süleymân-ı zamân, sultân-ı güzîn, pâdişâh-ı 'adl-ârâ, âfitâb-ı saltanat, pâdişâh-ı dîn-i İslâm, sultân-ı bahâr, şâh-ı 'adâlet-pîşe, şâh-ı cihân, pâdişâh-ı ins ü cân, kahramân-ı bahr ü ber, pâdişâh-ı emr-i Hak, hümâ-yı saltanat, mahbûbü'l-kulûb, şâh-ı 'alî-rütbe, vâris-i mülk-i Süleymân, mihr-i tâb-dâr-ı saltanat, şems-i Hudâ, pâdişâh-ı nükte-dân, mâh-ı saltanat, mihr-i sipihr-i ma'delet, Süleymân-ma‘delet" gibi sıfatlarla nitelendirilmiştir.

Mecmuada Sultan II. Mustafa'nın cülûsu için yazılmış manzumeler genellikle "bihamdi'llâh, habbezâ, hamdüli'llâh, zihî, yâ Rab şükür, müjde olsun, hezârân şükr ü minnet, çok şükr, bâreka'llâh, hamd ol Allâha ki, sad-hezârân hamd u şükr" gibi ifadelerle başlamakta ve şairler II. Mustafa'nın cülûsunu "müjde, sad mübârek-bâd, mübârek ola, Hak mübârek eylesün, müjdeler âfâka, sad-müjde, müjderes, müjde kıl âfâka” gibi kelimelerle ifade etmektedirler.

Mecmuada yer alan manzumelerde Sultan II. Mustafa'nın cülûsu, kış mevsiminin sona erip baharın gelmesi gibi görülmüştür. Sultan II. Mustafa ile birlikte adalet baharı esmeye başlamış ve gönüllerde taze goncalar yeşermiştir. Din ve devlet yeniden hayat bulmuştur. Gönlü gam ve kederle dolan cihan halkının gönlü ferahlamış ve cihan baştan başa nur ile dolmuştur. Mustafa isminin Peygamberimiz (s.a.v)'in ismi olmasından ötürü cihana dolan bu nur peygamberimizin nuruna benzetilmiştir. Sultan Mustafa İslâm dininin padişahı, dini ihya edici ve Allah'ın gölgesi olarak nitelendirilmiştir. Mecmuada yer alan bu söyleyişlerden bazıları örnek oluşturması hasebiyle aşağıda gösterilmiştir.

II. Mustafa’nın cülûsu ile dünya baştan başa aydınlanmış ve Muhammed Mustafa'nın nuru doğmuştur.

Müjde ey ḩalḳ-1 cihān kim 'ālem oldı pür-żiyā

Kim țulū` itdi bugün nūr-1 Muhammed Muștafāa (Sürûrî, vr. 10b-11a)

II. Mustafa'nın teşrifi ile adalet baharı esmeye başlamış ve gülbahçesinde taze bir gül açılmıştır: 
474 / RumeliDE Journal of Language and Literature Studies 2020.19 (June)

The journal of poems which were made for Sultan Mustafa II / Z. Efe (pp. 46o-493)

Bād-1 teşrīfüñ bahār-1 ' adle olduḳda vezān

Bir gül-i nev-bāde açıldı yine gülzārdan

(Nâzım, vr. 20b-21a)

Yedi ülkenin padişahı Sultan II. Mustafa'nın tahta geçmesiyle yeniden din ve devlet hayat bulmuştur:

Didiler pādişāh-1 heft-kişver

Yeñiden devlet ü dīne virüp cān

(Mâhir Abdullâh, vr. 24b-27a)

Kutlu talihi ile devletin başına geçtiğinde dünya baştan başa neşe ile dolmuş ve gönlü hüzünlü kimse kalmamıştır.

Yümn-i iḳbāl ile çün geçdi serïr-i devlete

Ser-be-ser şād oldı ‘ ālem ḳalmadı bir dil ḥazin ～(Mehmed Şeyhî, vr. 29a-b)

Cihanın övünme sebebi Hz. Peygamber'in adaşı olan II. Mustafa, yüce dinin yardımcısı ve Allah'ın gölgesidir:

Semiyy-i mefhar-1 'ālem şehen-şeh-i a' z̧am

$\mathrm{Mu}^{\prime}$ in-i dīn-i mükerrem o ẓ̂ll-1 cell [ü] celāl

(Zülâlî, vr. 32b-33b) 


\section{Şiirlerden örnekler ${ }^{25}$}

$1 .^{26}$

\section{Tārīhn-i Diger İmām-zāde Şükūfĩ Meḥemmed}

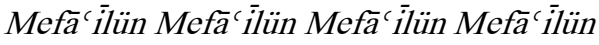

Cihān nūr-1 Muhammedden żiyā bulduġı pek zāhir

Ki Sultạn Muștafāa şāh-1 cihāndur düşmenin ḳāhir

'Adūsından kemāliyle murādı intikāàm almak

Dem-ā-dem şevḳ ile žātı bilüñ āmāde vü ḥāżır

Ma'ārifle vücūd-ı pāki pür-ziver huuṣușāa kim

Ġazā 'ilminde tìr atmaḳda seyf urmaḳda hep māhir

Hatạsaz eyleye Mevlā umūrında vire kuvvet

Ricālu'llāh ile te 'yid ide bi'zz-zāt ola nāṣır

Şükūfĩ didi zevk ile sürūrından gelüp nuṭka

Cülūs-1 taht-1 şehen-şāha tārīh oldı bil ẓāhir

\section{$2 .{ }^{27}$}

\section{Tārīh-i Diger Nazịim}

\section{Fā'ilātün Fā'ilātün Fā'ilātün Fā'ilün}

Yümn-i teşrîf-i ḳudūm-1 Vālide Sulțān ile

Maẓhar-1 sūr-1 sürūr dem-be-demdür Edrine

Şāh-rāh-1 devletinde rü 'yeti ferş eyleyüp İhtirām-1 maḳdemiyle muḥteremdür Edrine

Olsa her bir zerre şāyeste-i iksīi-i murād Vālide Sultạn tā hā̄k-i ḳademdür Edrine

Māder-i şāh-1 cihān şeh-zāde Sulțān Muștafā Kim zamānında z̧afer-yāb-1 sitemdür Edrine

Eyledi anda cülūs ol dāver-i Dārā-şükūh

Tahtgāh-1 şāh-1 İskender ḥaşemdür Edrine

Açsa lāyıḳdur livā-yı nușreti anda o şeh Vaṣf-1 Dārü’n-nașr ile zirā ‘ alemdür Edrine

Cilvegāh-1 Vālide Sulțān olaldan gūyiyā Perde-i ' iṣmet keşīe bir ḥaremdür Edrine

\footnotetext{
$25 \quad$ Makale sınırlarını gözeterek Mestap'a göre tasnif ettiğimiz ve manzumelerinden örnekler sunduğumuz mecmuayı esas alan inceleme ve tam metinden oluşan kitap çalışmamızı yakın bir zamanda yayımlamayı düşünüyoruz.

26 Mecmû'a-i Eş'âr, Nuruosmaniye Kütüphanesi 3700, vr. 14b-15a.

27 Mecmû'a-i Eş'âr, Nuruosmaniye Kütüphanesi 3700, vr. 15b. 
Didiler teşrifine ehl-i vilāyet ey Naz̧ìm Vālide Sultạn ḳudūmuñla İremdür Edrine

\section{$3 .^{28}$}

\section{Tārīh-i Diger Nāzī Çelebi}

Fā'ilātün Fā̄ilātün Fā'ilātün Fā‘ ilün

Ḥamdüli' llāh baht-1 dünyā açılup oldı sürūr Kā 'ināta bir şehüñ nāmını meşhūr eyledi

Çoḳ zamān idi ḩarāb olmuşdı ețrāf-1 cihān Ḥaḳ Te ālā yeñiden dünyāyı ma' mūr eyledi

Yümn ile itdi cülūs taht-1 sa ādet üstine Eyledi ' adle teveccüh sa' $y-1$ meşkūr eyledi

İbtidāsında Hudā iḥsān idüp elțāfını

Kāfirüñ donanmasın bir ḳulı maḳhūr eyledi

Yā İlāhī ‘ ömrin efzūn eyleyüp hem devletin Eyle dünyālar ḳadar ḩayrını mebrūr eyledi

Böyle mi eyler idüm şāhum cülūs-1 medhüñ̃i N'eyleyem bahtum beni gāaetde ma'zūr eyledi

Ḥamd idüp Nāzi cülūsına didi tārīhini Sāl-i Sultān Muștafāa dünyāyı mesrūr eyledi

\section{$4 .^{29}$}

\section{Tārihh-i Diger Faḳirī Çelebi}

\section{Fā'ilātün Fā'ilātün Fā‘ilātün Fācilün}

Cānib-i Ḥaḳdan hidāyet oldı Sulțān Mușțafā

Derdlü ḳullara selāmet oldı Sulțān Muștafā

Tahta devletle cülūs itdükde düşmen ḳahr olup Cümle küffāra 'alāmet oldı Sulțān Mușțafā

Cedd-i a lāsı kerāmetler ile yād oldılar Ḥāliyā șāhịib-velāyet oldı Sulțān Muștạaā

Hualḳ-1 ‘ālemden kesāfet ref ${ }^{\imath}$ olup ḥamd itdiler Kalb-i maḥzūna ḥalāvet oldı Sulțān Mușțafā

'Āleme çün pādişāh itdi anı ol Žü'l-celāl Ḥâliyā ṣāhib-kerāmet oldı Sulțān Mușțafā

28 Mecmû'a-i Eş'âr, Nuruosmaniye Kütüphanesi 370o, vr. 26b-27a.
29 Mecmû'a-i Eşâr, Nuruosmaniye Kütüphanesi 370o, vr. 34a. 
Haste-hạā olan Faḳirì didi tārīhin anuñ

Bize Mevlādan `ināyet oldı Sulțān Mușțafā

\section{$5 .^{30}$}

\section{Tārīh-i Diger Fenni Çelebi}

Fā'ilātün Fā'ilātün Fā'ilātün Fā'ilün

Mațla -1 burc-1 sa ādetden olup pertev-feşān

Eyledi nūr-1 Muhammed gibi dehri pür-żiyā

$S^{c}$ d-1 sāa atde idüp tahtt-1 şehen-şāha cülūs

'Ömrini devletle efzūn eyleye Bārihudā

Görmedi çeşm-i felek şāhān içinde hạk budur Böyle bir şāh-1 ' adālet-pişse vü șạ̄ib-ḥayā

Şīr-ṣavlet Kahraman-heybet Süleymān-ma' delet

Ḥâris-i mülk ü milel ser-çeşme-i cūd u 'ațā

Çıḳdı bir Hııżr-ı hııred Fennì didi tārīhini

Müjde oldı pādişāh şeh-zāde Sulțān Mușțafā

\section{$6 .^{31}$}

\section{Tārìh-i Diger Müstaḳim Çelebi}

\section{Fā'ilātün Fā'ilātün Fā'ilātün Fā'ilün}

Maẓhar-1 feyyāż-1 'ālem olduñ ey şāh-1 cihān

Eyledi şādān u ḥurrem ḥażret-i Mevlā sizi

Düşmen-i dīn üzre gāalib eyle ey Rabb-i celīl

Bulmadılar bir dahı deryāda kāfirden izi

Şol ḳadar ḳırdılar İslām ' askeri kāfirleri

Ķızıl Irmag̉a müşābih oldı deryānuñ yüzi

Sem '-i sulțāna irince çünki bu müjde didüm Huāne-ḳāhum yapmaḳ ile behre-yāb eyle bizi

Gūş idince Müstaḳim oldum didüm tārihhini Pādişāhum aldı İslām ' asker[i] bu Saḳızı

\footnotetext{
3o Mecmû’a-i Eş'âr, Nuruosmaniye Kütüphanesi 3700, vr. 14a-15a.

${ }_{31}$ Mecmû'a-i Eş'âr, Nuruosmaniye Kütüphanesi 370o, vr. 14b. 


\section{$7 .^{32}$}

\section{Tārīh-i Diger Ma`nevī}

Fā'ilātün Fā'ilātün Fā'ilātün Fā'ilün

Besmeleyle ḥamdeleyle kim ki ide fetḥ-i bāb

Ḥaḳ Te āalā ḳavlini fí lini meşkūr eyledi

Olmış iken bu fenā dünyā ḩarāb-ender-ḩarāb

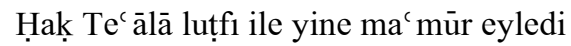

Hem șalāt olsun Ḥabībe āline aṣhābına

Kim șalāt ider aña zenbini mag̉für eyledi

Ḥaḳ Te ālā bir tecelli eyledi bu 'āleme

Dīn-i İslāmı anuñla cümle manșūr eyledi

Geldi Sulțān Muștafā şevket ile nuṣret ile

Ḥaḳ Te`ālā cümle maḥzūn göñli mesrūr eyledi

Enbiyā vü evliyānuñ ḥürmeti yā Rabbenā

Diyeler kạadir Hudūa a' dāyı maḳhūr eyledi

Mülkini ị̣sān idüp ol nūr iclās eyledi

Şer'-i pāke uymayanı şöyle menfūr eyledi

Sen ebu'l-feth [ü] ebu'n-nașr eyle anı yā rahīm Diyeler elḥamdü' lillāh dīni maḥșūr eyledi

Ma`nevī ol cism-i pāke şöyle tārīh eyle kim Nūr-1 pāk-i Muștạaa dünyāyı pür-nūr eyledi

\section{$8 .^{33}$}

\section{Tārīh-i Diger Mehemmed Şeyhī Mevlevi Be-hnāne-i Beşiktāş}

\section{Fā'ilätün Fā'ilātün Fā'ilātün Fā'ilün}

Ḥażret-i ẓıll-1 Hudā hem-nām-1 Sulțān-1 rüsül Ya'nīísultạn Muștafā ol dāver-i şevket ḳarīn

Yümn-i iḳbāl ile çün geçdi serīr-i devlete

Ser-be-ser şād oldı ‘ ālem ḳalmadı bir dil ḥazīn

Bā-huușūs a dā-yı bed-keşüñ donanmasın bozup

Fetḥ olunduḳda Saḳız mü'minler oldı kām-bīn

Ḥażret-i Ḥaḳdan temennāmuz budur kim ‘ an-ḳarīb

Fetḥ-i tabūr ile hem mesrūr olalar mü’minin

32 Mecmû'a-i Eş'âr, Nuruosmaniye Kütüphanesi 3700, vr. 17a.
33 Mecmû'a-i Eş'âr, Nuruosmaniye Kütüphanesi 3700, vr. 29a-29b. 
Nemçe küffārı perişān ola 'avn-i Ḥaḳk ile

Dest-i teshiire gele sā 'ir ḳılā́ ile Budin

Ṭālic oldı mațla' 1 şems-i Mehemmedden bu nūr

'Adl ile āfāḳ̂ tenvīi eyledi șad āferīn

Ḥak Te`ālā ‘ömrin efzūn devletin dā’im idüp

Kanda 'azm eylerse tevfīḳ-i Hudā ola mu' in

Şeyḩ $\bar{i}$ i dāc $\bar{i}$ sürūr u şevkle tārīh içün

Fikr iderken zāhir oldı ḳalb[üm]e semt-i güzīn

Rūḥ̂-1 pāk-i hażret-i Mollādan istimdād ile

Hูırmen-i eş ār-1 pākinden olınca dāne-çīn

Düşdi silk-i nuțke-1 Mevlānāda tārīh-i cülūs

Muștafā mā-cā'e illā rahmeten li'l- 'ālemīn

\section{9. ${ }^{34}$}

\section{Tārīhn-i Diger Ṭophāneli Meḥemmed Efendi}

Mefā‘īiün Mefā'īlün Mefā‘īiün Mefā'īlün

Te ālā'llāh ki bulduḳ feyż-i Ḥaḳdan nic met-i 'uẓmā

Feraḥ-nāk oldı 'ālem ser-te-ser şarḳā ilā garbā

Perişāan yüzin göstermiş iken çehre-i ' ālem

Nesìm-i luṭf-1 Rabbāniyle oldı mürdeler ihyā

Bize Ḥak ḳıldı Sultān Muṣtafã Huānı bir ị̣sān kim

Kemālince ne mümkin idebilmek şükrini icrā

Zamān-1 devletüñde oldı ‘ ālem hạal-i āsūde

Cülūsı ile irdi rāḥata dünyā vü mā-fîhā

Mübārek hāṭtırı hüzzn ü elemden dūr ola dā 'im Vücūd-1 pākini ḩavf-1 ḩațardan ḥıfẓ ide Mevlā

Hudā hoş̧ūd ola ābā vü ecdād-1 'iẓāmından Kamunuñ eyleye menzilgehini cennetü'l-me 'vā

Olar ḩāk içre yattukça İlāhi ḳ̂l bu sulțānı

'Adūsı üzre gāālib şevket ü şānını hem a' lā

Devām-1 devlet ü 'ömri du āsiyla muḳayyedken

Bir āvāz-ı ḩoş-elḥ̂an ḳıldı hātif eyledüm ıṣgàà

34 Mecmû'a-i Eş'âr, Nuruosmaniye Kütüphanesi 3700, vr. 29b-30a. 
Didi mümtāz olur düşdükçe bir tārihh tamām el-ḥak Selāmet buldı Sulțān Mușțafã ile cihān hạalā

$10 .^{35}$

\section{Tārīh-i Diger Havfī Çelebi}

Fā'ilātün Fā‘ ilātün Fā‘ ilātün Fā‘i ilün

Bāreka'llāh server-i sırr-1 İlāhì mühtedā

Pādişāh-1 ' ālem-ārā şehriyār-1 bā-șafā

İstinād-1 dīn ü devlet inbisātẹ ma delet

$M^{c}$ den-i fażl-1 ma ārif muḳtedā-yı ezkiyā’

Kām-rān-1 rükn-i a' zạm müftehāarr-1 haānedān

Mültecā-yı halk-1 `ālem mülteḳā-yı żi-` ațā

Mațlac -1 envār-1 şem ' i manẓar-1 erbāb-1 dil

Maḥzen-i esrār-1 luṭ̂ muḳteḍā-yı incilā

Emrüñe `ālem müsahhhar luṭfuña dünyā esīr Zātuña ș̣ḥ̣at mülāzım bahutuña ' izzet sezā

Mehd $\bar{i}-\mathrm{i}$ ‘ İ̀sā-nefes ki āsitān-1 ‘ àli-şān

Pertev-i māh-1 münīr eşref-i ‘ ayn-ı żiyā

Sac d-i ekber ḩāk-i pāyüñde sa ādet mültezem

' İzz ü cāh-1 mültemāsına sebīl-i ihtidā

Baḥr-1 cūdını taḩayyül eylemek emr-i muhāl Naṣb-1 tanșiṣsi meḳādìr bir huațā-yı iddic ā

Meşreb-i pākidür elbet çeşme-i āb-1 ḥayāt Mürde-dil ihyāsına var mı 'aceb bir ḳaṭe mā

Her ne emre iştigāal itseñ sa ādet feyż ola

Her ne yaña ' azm iderseñ ' avn-i Bārỉ reh-nümā

Göstere tìg-i şerārın zümre-i küffāra kim

Neşr ola rūy-1 zemīne düşmen-i hūn-1 'adā

Müşkilātuñ ide āsān Ḥaḳ kerīm [ü] lā-yezāl

Olmaya eksük cenābuñdan gürūh-1 irticā

Bī-kesüñ haddi degül hạk üzre medhüñ eylemek Muhtașar ta' ríf olur mı böyle memdūḥ̂-1 Hudā 
Șidḳ u ihlāșa du āyı idelüm şimden girü Şād-kām olsun serîr-i salțanatda dā 'imā

İstimāe idüp cülūsın Ḩavfiyā tārihh içün

'Ālemi tecdìid ide 'adliyle Sulțān Muștafāa

\section{$11 .^{36}$}

\section{Tārīh̆-i Diger İbrāhīm Efendi Der-Ḩāne-i Huașạa}

Fā'ilātün Fā'ilātün Fā'ilātün Fā'ilün

Ḥamdüli'llāh tāzelendi ' arṣa-i bāg̀ -1 cinān

Kim nesīm-i feyż irişdi häkkm ile sübḥāndan

Mihrveş oldı münevver hem vücūh-1 kā 'ināt Öyle bil kim dād-1 Ḥaḳdur fażl ile ị̣sāndan

$\mathrm{Na}^{\mathrm{c}}$ ra-i yā Hū șadāsın āşiyān-1 ḳudsiyān

Eylediler māverā-1 ḳubbe-i eflākdan

'Ālimi ' ālem-nümādur şehriyār-1 ma' delet Āṣafı Āṣaf-liḳādur dāver-i devrāndan

Nām-1 Ḥaydar 'aḳl Arisțo bir şeh-i haș̣let-güzīn $\mathrm{Bu}$ 'acebdür ki virilmiş ḥikmet-i Loḳmāndan

İntiḳām almaḳda şāha hüsrevānlıḳ vaḳtidür Her ' adū-yı bed-güher hem ẓālim-i bì-dāddan

Sāyeveş ẓ̂ll-1 hümāyūn sac $d$-ahtersin şehā Olalı bezm-i elestde kıısmet-i kassāmdan

Gösterür șāḥib-ḳıānlık țâlic -i ferhuundesi Öyle istidlāl olunmış șūret-i aḥkāmdan

Şehsüvār1 şevketini görse ger ḥāḳān-1 Çīn Terk iderdi hānumānı ziverin bir huākden

Vāriș-i Aḥmed Muḥammed çün 'Aliyyü’l-Mürteżā

Remz ider hū ile nūnı keşf ile keşşăfdan

Züül-Celālā 'ömr-i sermed rūz[ī] kı1l bu servere Āyet-i Furkān içinde hemçü ḳāf ü kāfdan

Didi Sulțān Muștafā çıḳdugì birle bir veli Oldı yā șāḥib zamān u nesl-i āl-' Oṣmāndan

\footnotetext{
${ }_{36} \quad$ Vr. $41 \mathrm{a}-42 \mathrm{~b}$
} 


\section{Sonuç}

Çalışmamızın konusunu teşkil eden ve Nuruosmaniye Kütüphanesi'nde 3700 numarada kayıtlı olan Mecmûa-i Tevârîh, mecmua geleneği içerisinde örneklerine az rastladığımız belli şahıslar adına tertip edilen mecmuaların bir örneğidir. Bu yönüyle 45 varaktan müteşekkil olan bu mecmua, çok hacimli olmamakla birlikte diğer mecmualar arasında önemli bir yere sahiptir.

Mecmua, 1106/1695 tarihinde tahta geçen Sultan II. Mustafa'nın cülûsu ve padişah tahta geçtikten sonra gerçekleşen Sakız Adası'nın fethi için çeşitli şairler tarafından yazılan manzumelerden oluşmaktadır. Toplam 100 manzumeyi ihtiva eden mecmuadaki manzumelerin 6'sı Arapça 5’i Farsçadır. Bu manzumeler mesnevi, kaside, terkib-i bend, kıt'a, nazım, koşma ve müfred nazım şekilleri ile kaleme alınmışlardır. En çok örneği görülen nazım şekli, kıt‘a ve nazımdır. Ayrıca mecmuada cülûsiyye, tarih ve arz-ı hâl gibi türlerin yer aldığı da görülmektedir.

Mecmuada yer alan manzumeler, 17. yüzyılın sonu ile 18. yüzyılın ilk çeyreğinde yaşamış olan 67 farklı şair tarafından kaleme alınmıştır. Bu şairler, genel itibarıyla devrinin tanınmış şairleri olmayıp II. Mustafa'nın çevresinden ve saraya yakın olan kişilerdir. Mecmuada yer alan şairlerin birçoğunun ilmiye sınıfına dâhil olduğu ve bu şairlerin birçoğunun Mevlevî ve Halvetî tarikatına mensup kişiler oldukları görülmektedir.

Mecmuadaki şiirlerin başlıklarında şairlerin kimlikleri, nereli oldukları ve meslekleri ile alakalı birtakım biyografik bilgiler de mevcuttur. Ancak mecmuada yer alan üç şiirin mahlası bulunmadığı ve başlığında da şiirin kime ait olduğuna dair herhangi bir kayıt olmadığı için bu üç şiirin şairi tespit edilememiştir. Ayrıca mecmuada tezkirelerde ve biyografik kaynaklarda ismine rastlayamadığımız şairler de yer almaktadır.

Mecmuada yer alan manzumeler, edebî açıdan sahip oldukları önemin yanında birtakım tarihî olaylar hakkında da bilgiler sunmaktadır. Padişaha sunulan cülûsiye kasideleri, şairlerin dilek ve isteklerini dile getirdikleri arz-ı hâller ve Sakız Adası'nın fethi için düşürülen tarihler yazıldıkları döneme ışık tutmaktadır. Devlet yönetimindeki aksamalar, rüşvet ve zulmün artması, liyakatin kalmaması, irfan ehlinin itibar görmemesi ve toplumun içinde bulunduğu ruh hali şiirlere konu edilen toplumsal olaylardır. Ayrıca mecmuada yer alan şiirler padişah tahta geçtiğinde yapılan bazı merasimler hakkında verdiği bilgilerle döneminin sosyal olayları hakkında da bilgiler sunmaktadır.

Yapılan bu çalışma ile mecmua geleneği içerisinde önemli bir yere sahip olan bir mecmua daha ilim âleminin istifadesine sunulmuş ve mecmuaların hem edebiyat tarihimize sağladığı katkılar hem de döneminin tarihî olayları hakkında bilgiler sunması hasebiyle sahip olduğu önem bir kez daha vurgulanmıştır.

\section{Kaynakça}

Abdulkadiroğlu, A. (1985). İsmail Beliğ Nuhbetü’l-âsâr Li-Zeyli Zübdeti’l-Eş’âr. Ankara: Gazi Üniversitesi Gazi Eğitim Fakültesi Yayını.

Aksoyak, İ. H. (2013). Müstakîm, Mehmed Müstakîm Efendi. Türk Edebiyat İsimler Sözlüğü. [Erişim Tarihi: 05. 11. 2020], http://teis.yesevi.edu.tr/madde-detay/mustakim-mehmed-mustakimefendi.

Aksoyak, İ. H. (2014). Devletî, Çerkes Ahmed Çelebi. Türk Edebiyatı İsimler Sözlüğü. [Erişim Tarihi: 05. 11. 2020], http://teis.yesevi.edu.tr/madde-detay/devleti-cerkes-ahmed-celebi. 
Altuner, N. (1989). Safââ ve Tezkiresi İnceleme-Tenkitli Metin-İndeks. İstanbul: İstanbul Üniversitesi Sosyal Bilimler Enstitüsü Doktora Tezi.

Arkun, K. (2010). Dünyaya Nizâm Verenler Sultan II. Mustafa Han. İstanbul: Akademisyen Yayınevi.

Ayhan, E. (2000). Nakşî Dîvânı. İstanbul: Marmara Üniversitesi Sosyal Bilimler Enstitüsü Yüksek Lisans Tezi.

Aynur, H. ve Şen, F. M. (2019). "Hıfzî Ağa'nın (ö. 1173/1759-6o) I. Mahmûd İçin Yazılan Şiirler Mecmûası (TSMK-Revan 1977) Üzerine”, Akademik Dil ve Edebiyat Dergisi, 3 (4), s. 39-73.

Aypay, İ. (1992). Nahîfí Süleyman Efendi (Hayatı, Eserleri, Edebî Kişiliği ve Dîvânı'nın Tenkitli Metni). Konya: Selçuk Üniversitesi Sosyal Bilimler Enstitüsü Doktora Tezi.

Baltalı, S. (2016). Mehmed Adlî Divanı. Kırklareli: Kırklareli Üniversitesi Sosyal Bilimler Enstitüsü Yüksek Lisans Tezi.

Bayram, Ö. (2013). Abdî, Himmetzâde. Türk Edebiyat İsimler Sözlüğü. [Erişim Tarihi: 05. 11. 2020], http://teis.yesevi.edu.tr/madde-detay/abdi-himmetzade.

Bülbül, T. (2014). Zülâlî, Enderunlu Hasan Efendi. Türk Edebiyat İsimler Sözlüğü. [Erişim Tarihi: o5. 11. 2020], http://teis.yesevi.edu.tr/madde-detay/zulali-enderunlu-hasan-efendi.

Ceyhan, Â. (1990). Enîs Receb Dede (?-1733) Hayatı, Edebî Şahsiyeti ve Eserleri: Dîvânı. İstanbul: Marmara Üniversitesi Sosyal Bilimler Enstitüsü Yüksek Lisans Tezi.

Çakır, M. S. (2018). Yahyâ Nazîm Divanı (İnceleme-Tenkitli Metin). Sivas: Sivas Cumhuriyet Üniversitesi Sosyal Bilimler Enstitüsü Doktora Tezi.

Çibir, Ş. (2016). Maziye Hasret Sultan II. Mustafa “Cengâver". İstanbul: Parola Yayınları.

Demirsoy, S. (2010). Vekâyi'i-i Ali Paşa (İnceleme-Metin). İstanbul: Mimar Sinan Güzel Sanatlar Üniversitesi Sosyal Bilimler Enstitüsü Yüksek Lisans Tezi.

Ekinci, R. (2018). Vekayiü'l-Fuzala Şeyhi’nin Şakaik Zeyli. İstanbul: Türkiye Yazma Eserler Kurumu Başkanlığı Yayınları.

Erdem, M. (1994). Bursah Talib ve Divanı Tenkidli Metin ve İnceleme. İstanbul: Boğaziçi Üniversitesi Yüksek Lisans Tezi.

Ertek Morkoç, Y. (2003). Eğridirli Hacı Kemalïn Câmiü’n-Nezâir’i (Metin ve Mecmua Geleneği Üzerine Bir İnceleme). İzmir: Ege Üniversitesi Sosyal Bilimler Enstitüsü Doktora Tezi.

Gıynaş, K. (2017). Pervâne Bey Mecmuası, Ankara: KTB. Yayınları. [Erişim Tarihi: 11.05.2020]. e-kitap: https://ekitap.ktb.gov.tr/Eklenti/55832,pervane-bey-mecmuasi-pdf.pdf?o.

Gümüş, N. (2014). Nazîm, Yahya Çelebi. Türk Edebiyatı İsimler Sözlüğü. [Erişim Tarihi: 05. 11. 2020], http://teis.yesevi.edu.tr/madde-detay/nazim-yahya-celebi.

Gürbüz, Mehmet (2012), "Şiir Mecmûaları Üzerine Bir Tasnif Denemesi”, Eski Türk Edebiyatı Çalışmaları VII: Mecmûa: Osmanl Edebiyatının Kırkambarı, (Haz.: Hatice Aynur vd.), İstanbul: Turkuaz Yayın. s. 97-113.

Hakverdioğlu, M. (2007). Edebiyatımızda Lâle Devri ve Nevşehirli Dâmat İbrâhim Paşa'ya Sunulan Kasideler İnceleme-Metin. Selçuk Üniversitesi Sosyal Bilimler Enstitüsü Doktora Tezi.

İçli, A. (2017). "Nigînî, Mecmuası ve Şiirlerinden Örnekler", Türkiyat Araştırmalarn Enstitüsü Dergisi, 58, s. 129-157.

İçli, A. (2018). “Kâsımî Mecmuası'nın İçerik Analizi”, Karadeniz Uluslararası Bilimsel Dergi, 40, s. 468499.

İnan, G. (2013). Ahmed Hasîb Efendïnin Mecmûa-i Tevârîh'i. Edirne: Trakya Üniversitesi Sosyal Bilimler Enstitüsü Yüksek Lisans Tezi.

İnce, A. (2018). Tezkiretü’s-şuarâ Mîrzâ-zâde Mehmed Sâlim Efendi. Ankara: KTB. Yayınları. [Erişim Tarihi: 11.05.2020]. e-kitap: https://ekitap.ktb.gov.tr/Eklenti/57124,mirza-zade-mehmedsalim-tezkiretu39s-su39arapdf.pdf?o. 
İsen, M., Bilkan, A. F. ve Durmuş, T. I. (2012). Sultanların Şïrleri Şïrlerin Sultanları. İstanbul: Kapı Yayınları.

Kaplan, H. (2018). "Divan Edebiyatında Sakız ve Sakız’n Fethinin Edebiyatın Nükte Dünyasına Yansimaları". Ekev Akademi Dergisi, 73, 367-394.

Kaplan, Y. (2018). "İstanbul Üniversitesi Nadir Eserler Kütüphanesi'nde Kayıtlı 5480 Numaralı Musammat Mecmuası Üzerine”, Divan Edebiyatı Araştırmaları Dergisi, İstanbul. Güz, Sayı 21. s. 401-540.

Kaplan, Y. (2013). "Milli Kütüphane "Yz. A 7521” Numaralı Şiir Mecmuası Üzerine” Selçuk Üniversitesi Türkiyat Araştırmaları Enstitüsü, Türkiyat Araşttrmaları Dergisi, Konya. Sayı 33, s. 89-114.

Kaplan, Y. ve Efe, Z. (2020). "Defterdar Mehmed Behcet Efendi'ye Sunulan Şiirler Mecmuası", Yayım aşamasında olan çalışma.

Karacan, T. (1991). Bosnalı Alaeddin Sabit: Divan. Sivas: Cumhuriyet Üniversitesi Yayınları.

Karavelioğlu, M. A. (2014). Nahîfî, Süleyman. Türk Edebiyatı İsimler Sözlüğü. [Erişim Tarihi: 05. 11. 2020], http://teis.yesevi.edu.tr/madde-detay/nahifi-suleyman.

Kesik, B. (2014). Adlî, Süleymanzâde Mehmed Efendi. Türk Edebiyat İsimler Sözlüğü. [Erişim Tarihi: 05. 11. 2020], http://teis.yesevi.edu.tr/madde-detay/adli-suleymanzade-mehmed-efendi.

Kesik, B. (2014). Füyûzî, Mehmed Füyûzî Efendi. Türk Edebiyat İsimler Sözlüğü. [Erişim Tarihi: o5. 11. 2020], http://teis.yesevi.edu.tr/madde-detay/fuyuzi-mehmed-fuyuzi-efendi.

Kesik, B. (2014). Vahyî, Şeyh Mehmed Efendi. Türk Edebiyat İsimler Sözlüğü. [Erişim Tarihi: 05. 11. 2020], http://teis.yesevi.edu.tr/madde-detay/vahyi-seyh-mehmed-efendi.

Kılıç, Atabey (2012), "Mecmûa Tasnifine Dâir" Eski Türk Edebiyatı Çalışmaları VII: Mecmûa: Osmanlı Edebiyatınm Kırkambarı, (hazırlayanlar: Hatice Aynur ve öte.), Turkuaz, Istanbul, s. 75-96.

Koncu, H. ve Çakır, M. (2012). Şairleri Yetiştiren Bir Kaynak Olarak Mecmua. Eski Türk Edebiyatı Çalışmaları VII, Mecmûa: Osmanlı Edebiyatının Kırkambarı, İstanbul: Turkuaz, s. 120.

Köksal, F. (2016). "Kastamonulu İshâk-zâde Fevzî Mecmuası", Yâ Kebîkeç. İstanbul: Kesit Yayınları.

Köksal, M. (2011). Edirneli Nazmî-Mecma'u’n-Nezâìr, (İnceleme-Tenkitli Metin), Ankara: KTB. Yayınları. [Erişim Tarihi: 11.05.2020]. e-kitap: https://ekitap.ktb.gov.tr/Eklenti/56057,mecmaun-nezair-edirneli-nazmi-pdf.pdf?o.

Köksal, M. F. (2012). "Şiir Mecmualarının Önemi ve Mecmuaların Sistematik Tasnifi Projesi (MESTAP)", Eski Türk Edebiyatında Tenkit ve Teori, İstanbul: Kesit Yayınları. s. 83-101.

Kurnaz, C. ve Aydemir, Y. (2013). Mecmualara Sorulması Gereken Sorular. Turkish Studies, 8 (1), s. 53.

Kurnaz, C. ve Tatcı, M. (2001). Mehmed Nâil Tuman Tuhfe-i Nâilî. Ankara: Bizim Büro Yayınevi.

Kut, G. (1986). “Mecmua”. Türk Dili ve Edebiyatı Ansiklopedisi. C. 6. İstanbul: Dergâh Yay. 170.

Levend, A. S. (1998). Türk Edebiyatı Tarihi, I. Cilt. Ankara: Türk Tarih Kurumu. s. 166-67.

Mermer, K. (2013). Ma'nevî, Mustafa Manevî. Türk Edebiyat İsimler Sözlüğü. [Erişim Tarihi: 05. 11. 2020], http://teis.yesevi.edu.tr/madde-detay/manevi-mustafa-manevi.

Önkaş, A. N. (2013). Enîs, Receb Dede. Türk Edebiyat İsimler Sözlüğü. [Erişim Tarihi: 05. 11. 2020], http://teis.yesevi.edu.tr/madde-detay/enis-receb-dede.

Örenç, A. F. (2009). "Sakız Adası”, TDV İslâm Ansiklopedisi, 36, s. 6-10.

Özcan, A. (2006). "Mustafa II", TDV İslam Ansiklopedisi, 31, s. 275-280.

Özerol, N. (2013). Ârif Efendi. Mecmû‘a-i Eş‘âr: III. Selim’le ilgili şürler. Malatya: Serhat Matbaacılık.

Piroğlu, H. (2019). Topkapı Sarayı Müzesi Kütüphanesinde E.H.1487 Numarayla Kayıtl Bir Mecmûai Tevârîh (İnceleme-Metin). İstanbul: Ylldız Teknik Üniversitesi Sosyal Bilimler Enstitüsü Yüsek Lisans Tezi. 
Selçuk, B. (2014). Ârif/Ahî, Mehmed Ârif Efendi. Türk Edebiyatı İsimler Sözlüğü. [Erişim Tarihi: o5. 11. 2020], http://teis.yesevi.edu.tr/madde-detay/arif-ahi-mehmed-arif-efendi.

Taş, H. (2017). Vahŷ̂ Dîvanı. Ankara: KTB. Yayınları. [Erişim Tarihi: 11.05.2020]. e-kitap: https://ekitap.ktb.gov.tr/Eklenti/55745,vahyi-divanipdf.pdf?o.

Tuğluk, H. İ. (2014). Tâlib. Türk Edebiyat İsimler Sözlüğü. [Erişim Tarihi: 05. 11. 2020], http://teis.yesevi.edu.tr/madde-detay/talib.

Uzun, M. (2003). "Mecmua”. İslam Ansiklopedisi. C. 28. Ankara: TDV Yay. 265.

Yakar, H. İ. (2014). Abdullah Mâhir Efendi. Türk Edebiyatı İsimler Sözlüğü. [Erişim Tarihi: 05. 11. 2020], http://teis.yesevi.edu.tr/madde-detay/abdullah-mahir-efendi.

Yıldız, E. ve Batur, H. (2019). "Fransa Milli Kütüphanesi Türkçe Yazmalar Bölümü 1035 Numarada Kayıtlı Şiir Mecmuasının MESTAP’a Göre Tasnifi”, Külliyat Osmanlı Araştırmaları Dergisi, 7, s. 17-72. 
486 / RumeliDE Journal of Language and Literature Studies 2020.19 (June)

The journal of poems which were made for Sultan Mustafa II / Z. Efe (pp. 46o-493)

\begin{tabular}{|c|c|c|c|c|c|c|c|c|c|c|c|c|}
\hline 蛋 & 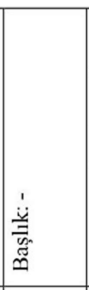 & |: & 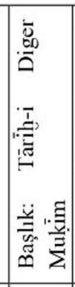 & 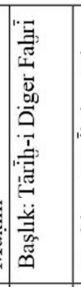 & 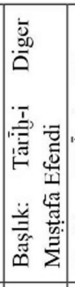 & 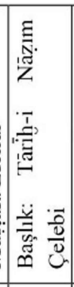 & 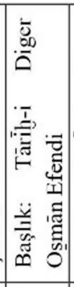 & 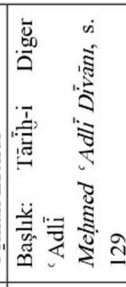 & 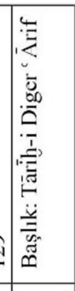 & 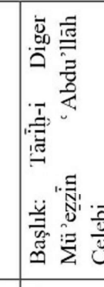 & 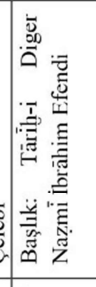 & 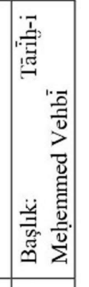 \\
\hline 量 & . & . & 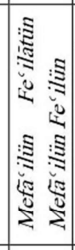 & 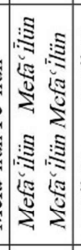 & 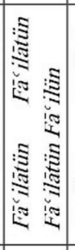 & 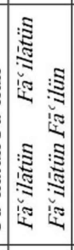 & 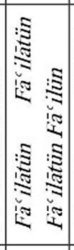 & 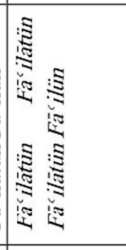 & 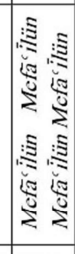 & 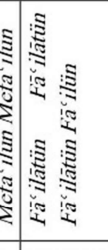 & 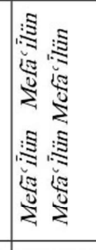 & 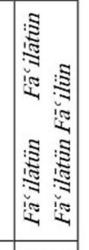 \\
\hline 具是 & 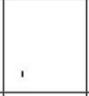 & . & 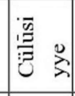 & : & 霄 & 㯊 & 䨐 & 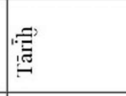 & 窢 & : & : & : \\
\hline 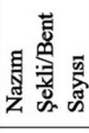 & & , & 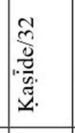 & 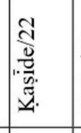 & 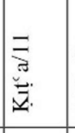 & 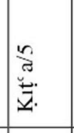 & 产 & 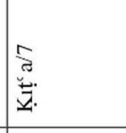 & 毵 & 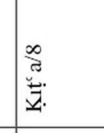 & 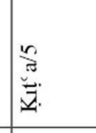 & 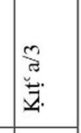 \\
\hline 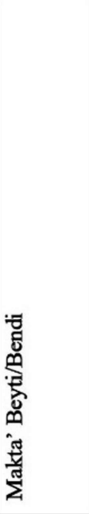 & 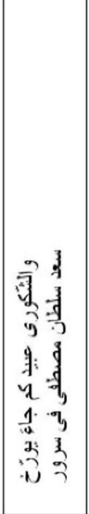 & 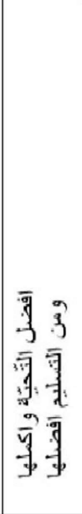 & 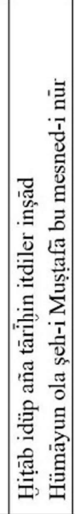 & 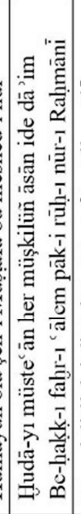 & 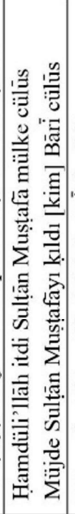 & 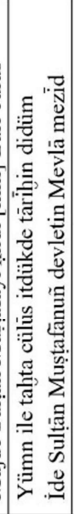 & 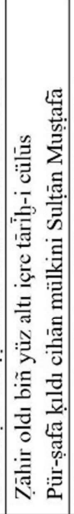 & 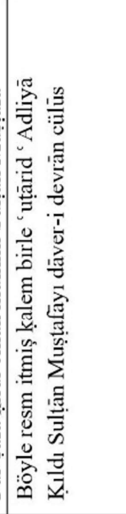 & 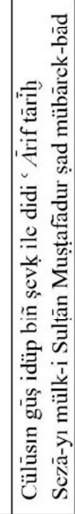 & 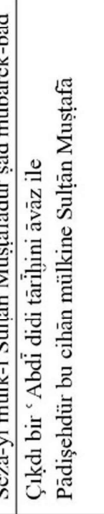 & 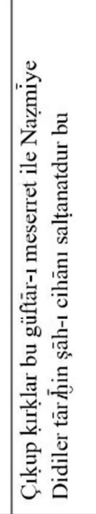 & 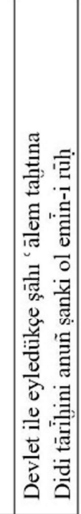 \\
\hline 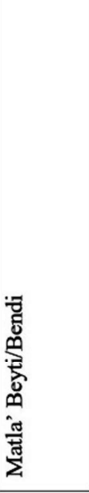 & 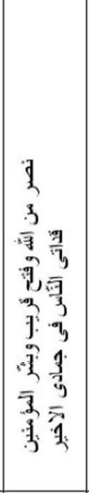 & 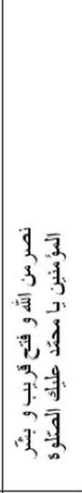 & 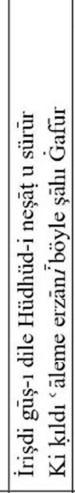 & 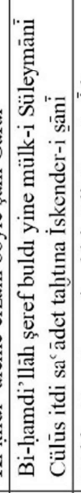 & 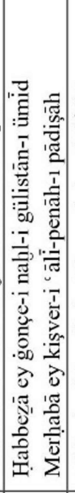 & 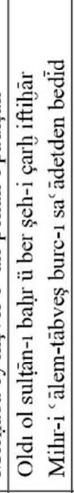 & 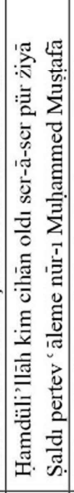 & 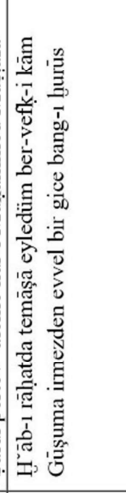 & 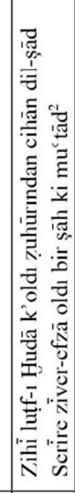 & 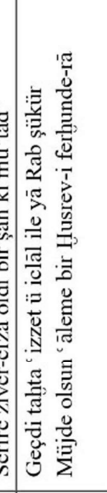 & 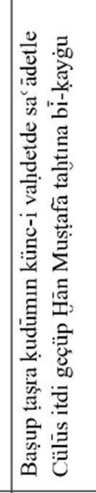 & 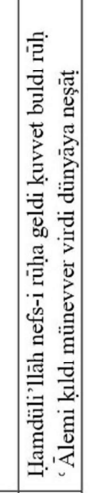 \\
\hline 昫 & 要 & |: & 喜 & "寻 & 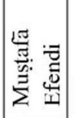 & 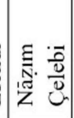 & & 余 & 空 & 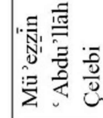 & & 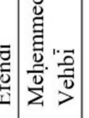 \\
\hline 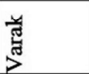 & 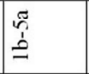 & 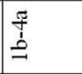 & $\dot{~ ल े ~}$ & 字 f & $\dot{f} \approx$ & $\Leftrightarrow 2$ & $\frac{1}{\operatorname{mon}} \mathrm{b}$ & $n$ & $\frac{1}{\omega n} g$ & 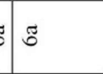 & t) & 8 \\
\hline
\end{tabular}




\begin{tabular}{|c|c|c|c|c|c|c|c|c|c|c|c|c|}
\hline & 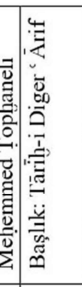 & 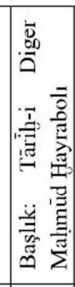 & 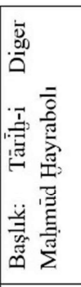 & 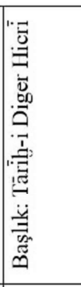 & |: & 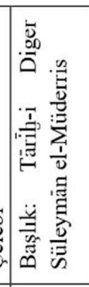 & 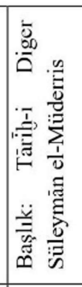 & 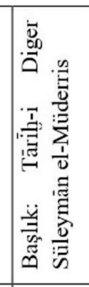 & 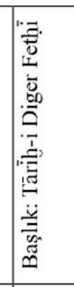 & 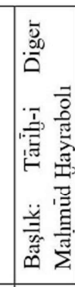 & 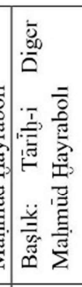 & 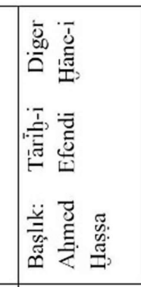 \\
\hline & 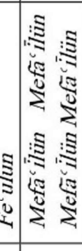 & 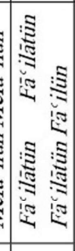 & & & 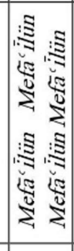 & & . & & 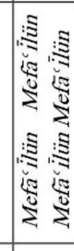 & 新 & 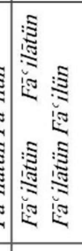 & \\
\hline & : & : & & & 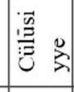 & & . & & 㯊 & 营 & 湑 & \\
\hline & 留 & 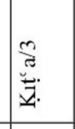 & & & 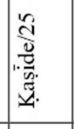 & . & . & . & 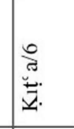 & 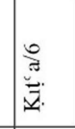 & 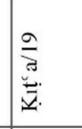 & . \\
\hline 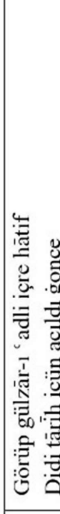 & 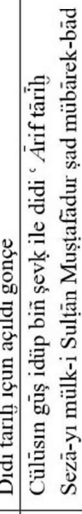 & 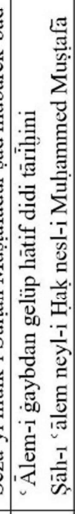 & 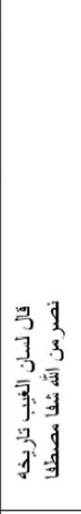 & 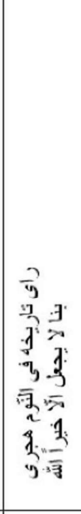 & 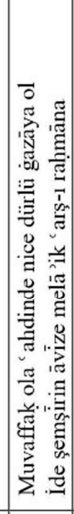 & 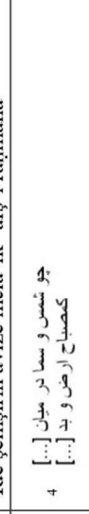 & 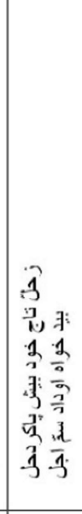 & 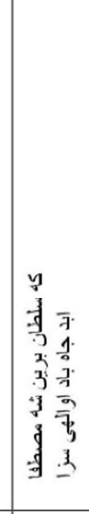 & 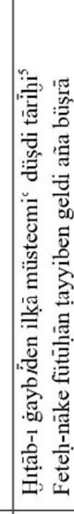 & $\begin{array}{l}: \\
\vdots\end{array}$ & 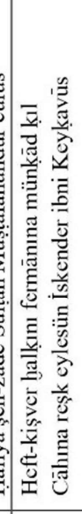 & 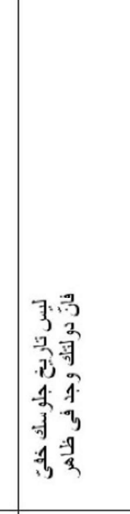 \\
\hline & 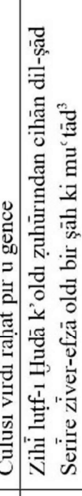 & 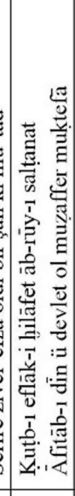 & 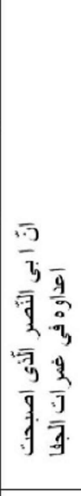 & 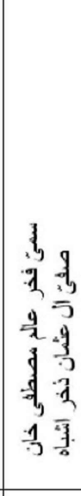 & 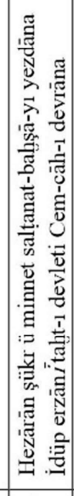 & 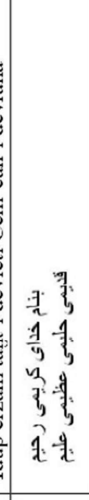 & 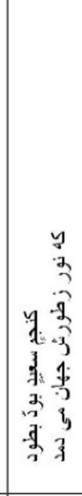 & 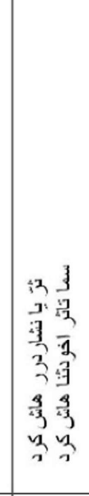 & 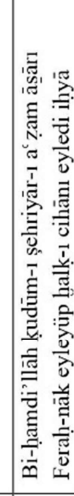 & 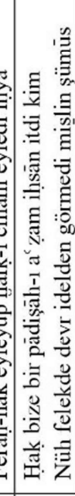 & 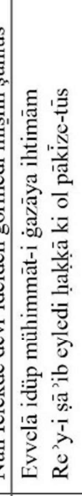 & 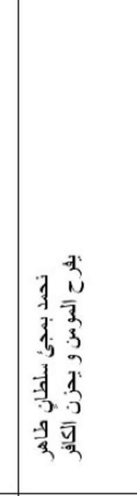 \\
\hline & & 苞 & 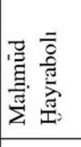 & 泀 & 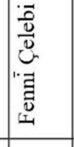 & 量 & 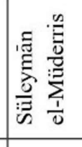 & 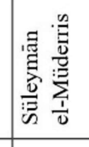 & . & 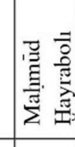 & 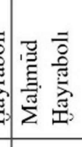 & \\
\hline & bे & $\because$ & $\therefore$ & $\frac{i}{2} \therefore$ & t่ & $\dot{\hat{R}} \ddot{\infty}$ & $\dot{\dot{\infty}} \ddot{\infty}$ & $\dot{1}$ & 2 & 2 & 형 & 实 $\triangleq$ \\
\hline
\end{tabular}


488 / RumeliDE Journal of Language and Literature Studies 2020.19 (June)

The journal of poems which were made for Sultan Mustafa II / Z. Efe (pp. 46o-493)

\begin{tabular}{|c|c|c|c|c|c|c|c|c|c|c|c|c|c|}
\hline 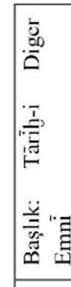 & 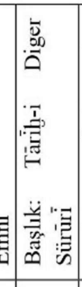 & 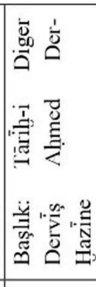 & 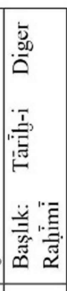 & 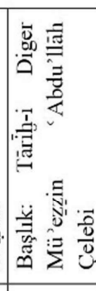 & 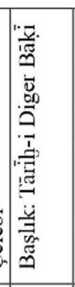 & 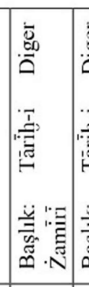 & 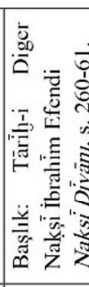 & 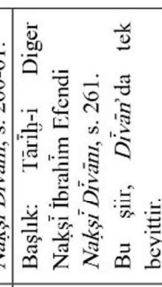 & 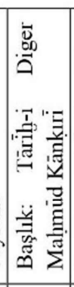 & 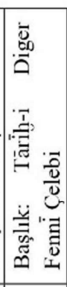 & 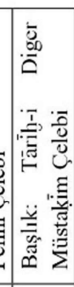 & 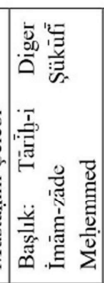 & 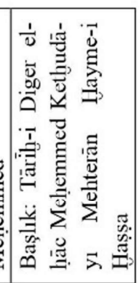 \\
\hline 空 & 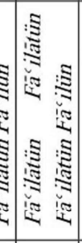 & 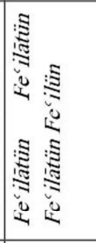 & 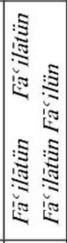 & 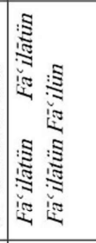 & 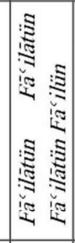 & 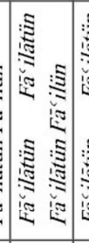 & 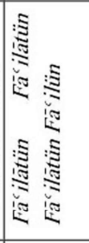 & 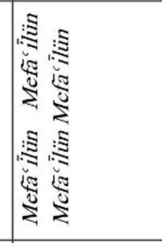 & 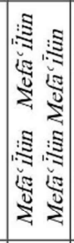 & 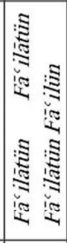 & 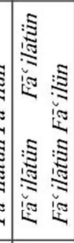 & 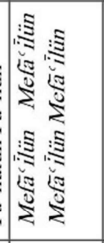 & 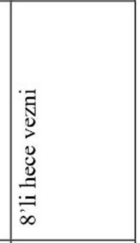 \\
\hline है & 莺 & 僵员 & 莺 & 覀 & 胥 & 䖪 & 霄 & : : & : & 营 & 局 & 䨐 & \\
\hline 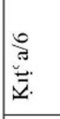 & 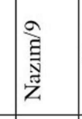 & 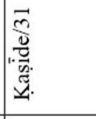 & 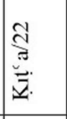 & $\frac{\frac{1}{3}}{\tilde{z}}$ & \begin{tabular}{|l|}
$\overrightarrow{\mid}$ \\
言 \\
公 \\
\end{tabular} & 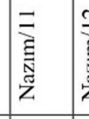 & 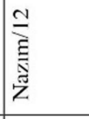 & $\begin{array}{l}\text { 章 } \\
\text { 崖 }\end{array}$ & 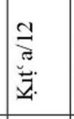 & 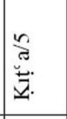 & $\mid \begin{array}{l}\tilde{n} \\
\bar{z} \\
\bar{\Sigma}\end{array}$ & 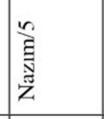 & 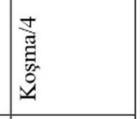 \\
\hline 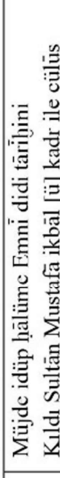 & 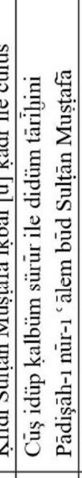 & 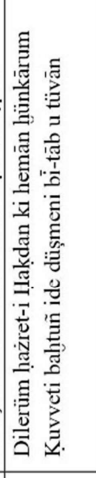 & 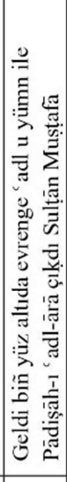 & 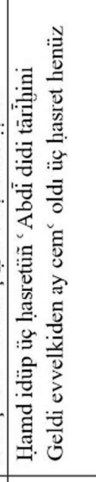 & 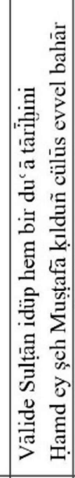 & 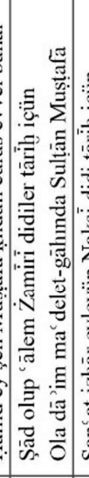 & 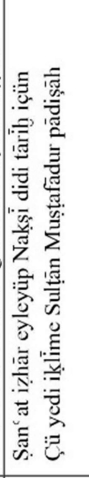 & 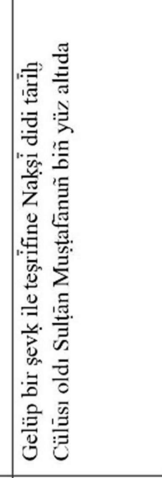 & 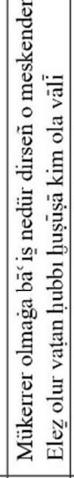 & 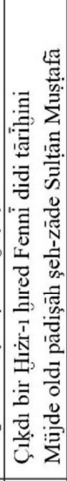 & 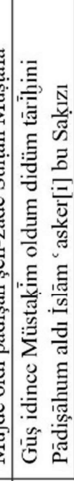 & 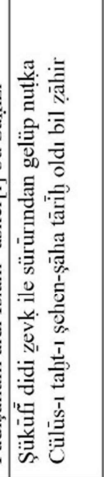 & 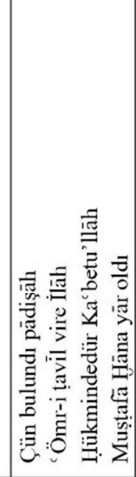 \\
\hline 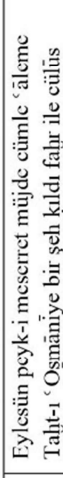 & 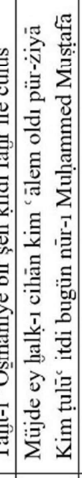 & 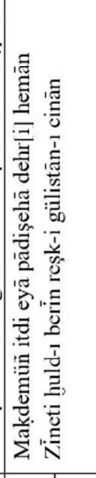 & 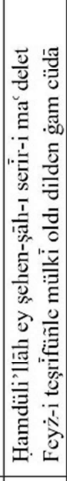 & 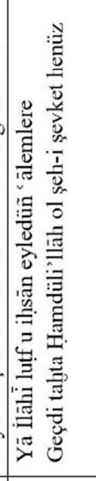 & 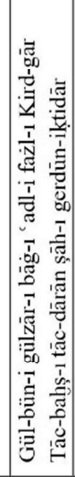 & 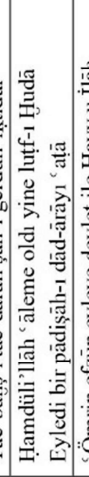 & 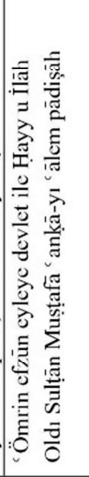 & 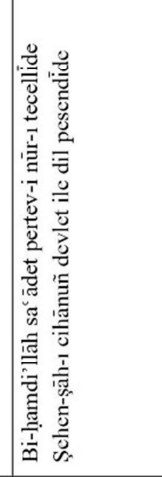 & 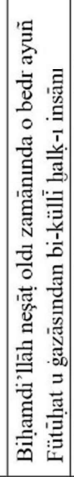 & 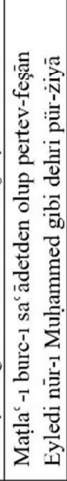 & 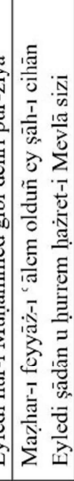 & 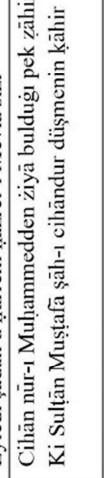 & 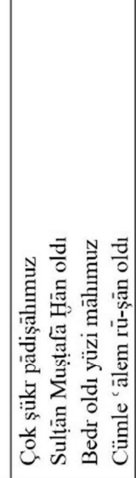 \\
\hline "㤩 & 湛 & 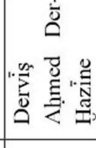 & $\ddot{\sim}$ & 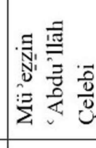 & 䳝 & ": & 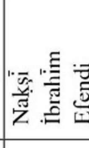 & 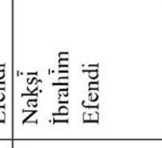 & 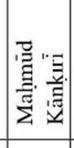 & & $\sum \mathrm{s}$ & & \\
\hline छे & $\dot{b} \stackrel{\Xi}{=}$ & $\Xi$ & 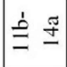 & ปี่ & 守 & $\stackrel{\dot{\mathscr{O}}}{0}$ & $\stackrel{\rho}{9}$ & 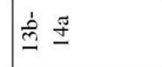 & 亲导 & 守号 & 毛 & 守 & $\check{\check{\pi}}$ \\
\hline
\end{tabular}




\begin{tabular}{|c|c|c|c|c|c|c|c|c|c|c|}
\hline 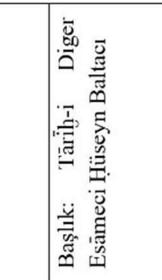 & 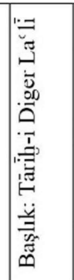 & 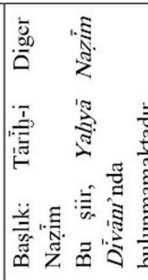 & 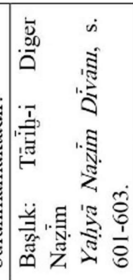 & 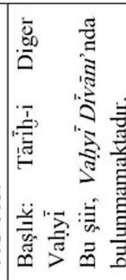 & 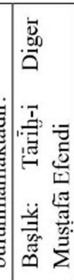 & 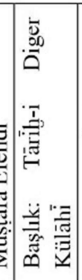 & 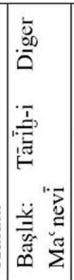 & 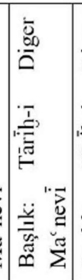 & 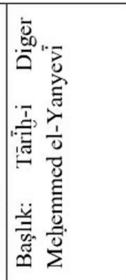 & 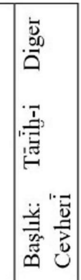 \\
\hline 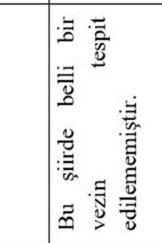 & 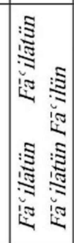 & 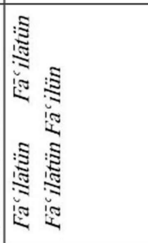 & 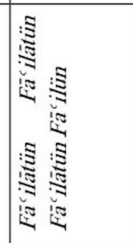 & 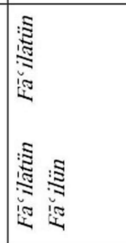 & 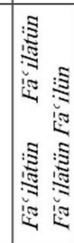 & 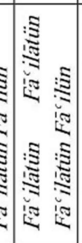 & 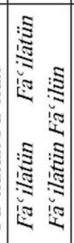 & 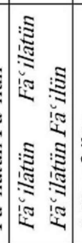 & 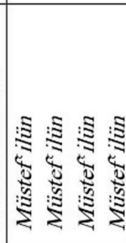 & s. \\
\hline 湥 & 㸃 & 莺 & 胥 & 容 & : : & 楚 & 焉 & 漂 & 莺 & \\
\hline $\mid$ & 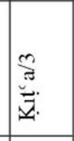 & 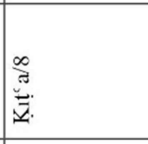 & 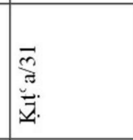 & 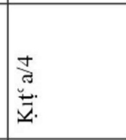 & 商 & 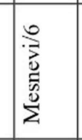 & 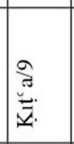 & 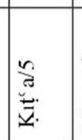 & 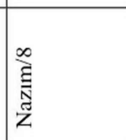 & 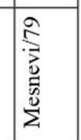 \\
\hline 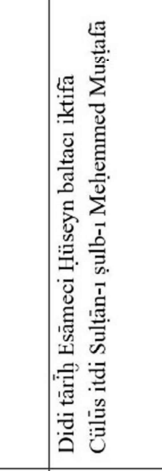 & 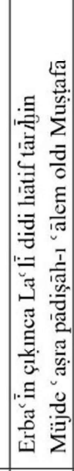 & 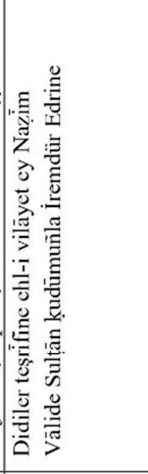 & 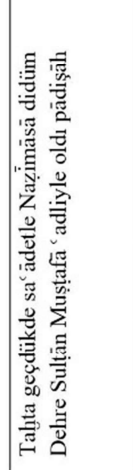 & 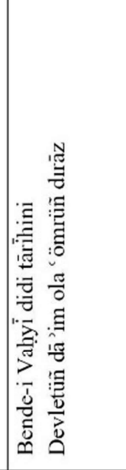 & 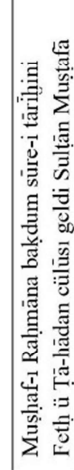 & 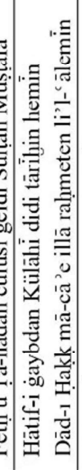 & 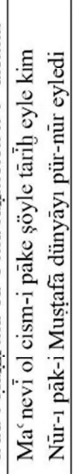 & 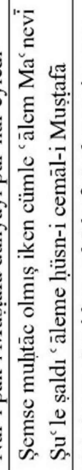 & 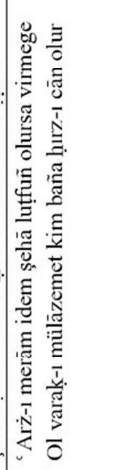 & 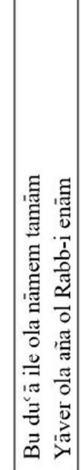 \\
\hline 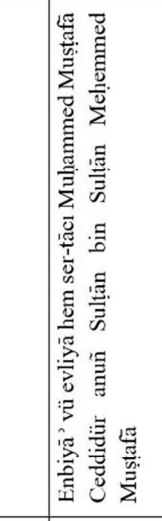 & 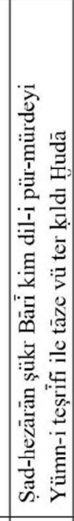 & 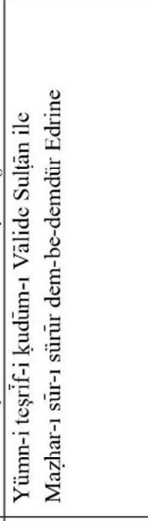 & 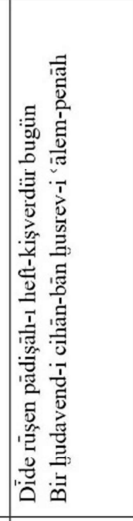 & 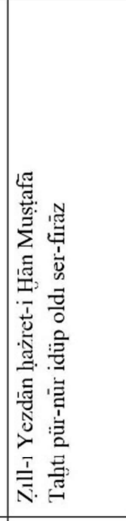 & 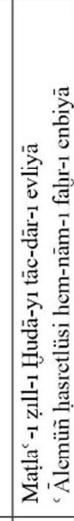 & 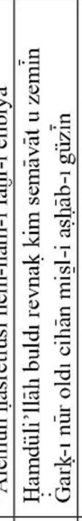 & 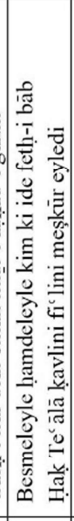 & 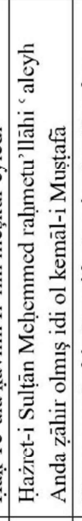 & 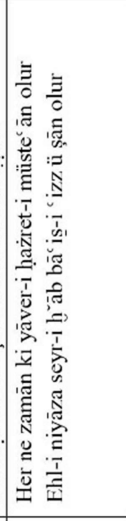 & 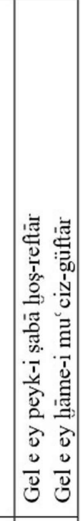 \\
\hline 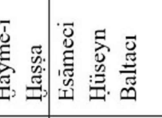 & = & | & 是 & | & 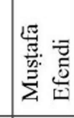 & 5 & 告 & | & 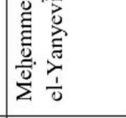 & "n \\
\hline 窎 点 & 离 & n़ & 咅 空 & $\frac{1}{\underline{n}} \stackrel{g}{-}$ & 离 & 0 & $\Xi$ & 홀 오 & 음 & 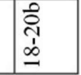 \\
\hline
\end{tabular}


490 / RumeliDE Journal of Language and Literature Studies 2020.19 (June)

The journal of poems which were made for Sultan Mustafa II / Z. Efe (pp. 46o-493)

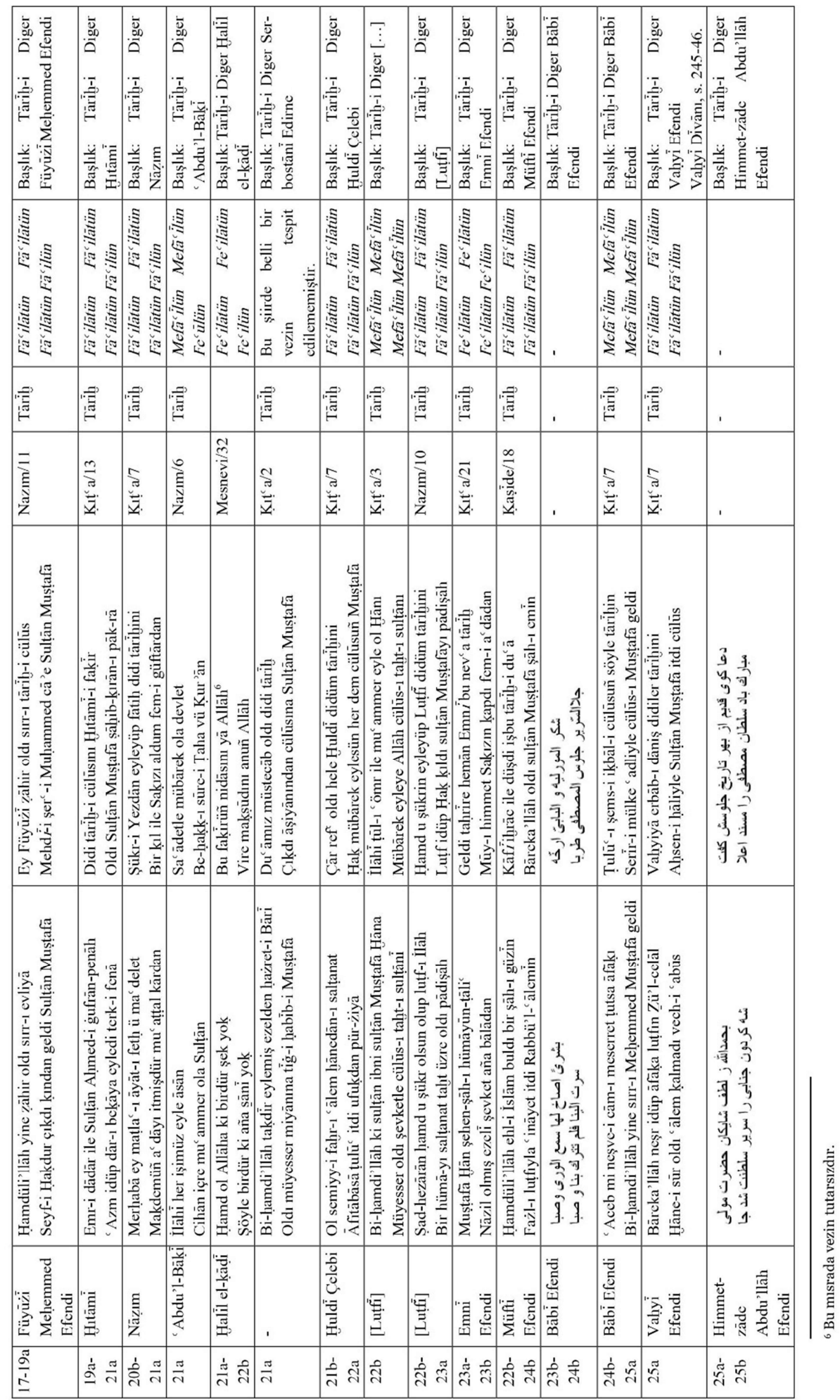




\begin{tabular}{|c|c|c|c|c|c|c|c|c|c|}
\hline 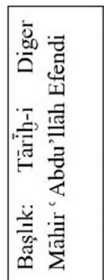 & 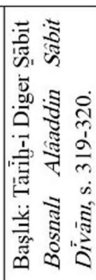 & 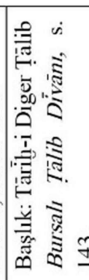 & 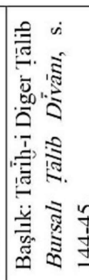 & 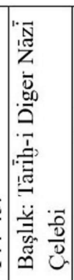 & 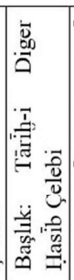 & 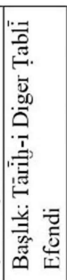 & 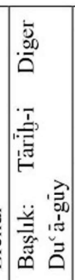 & 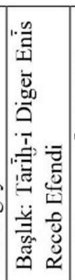 & 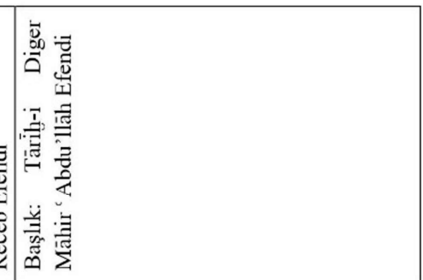 \\
\hline : & 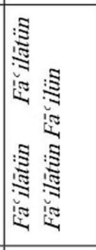 & 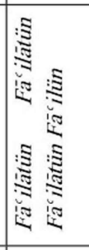 & 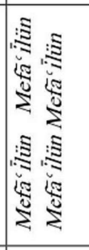 & 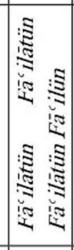 & 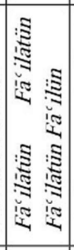 & 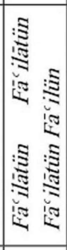 & 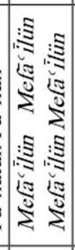 & 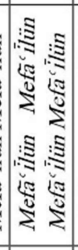 & 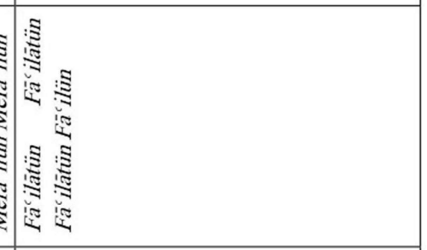 \\
\hline & 量 & 趸 & 窵 & 莺 & 胥 & 营 & 覀 & 到 & \\
\hline & 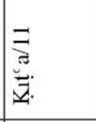 & 竞 & $\begin{array}{l}\frac{m}{s} \\
\bar{z} \\
\bar{z}\end{array}$ & 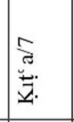 & 裹 & 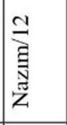 & 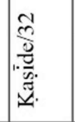 & 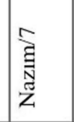 & 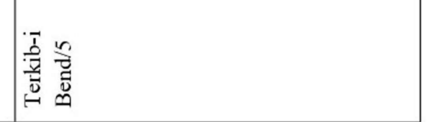 \\
\hline 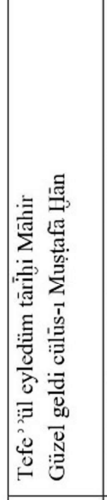 & 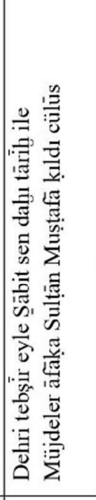 & 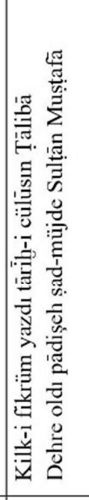 & 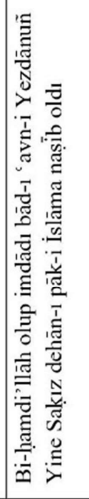 & 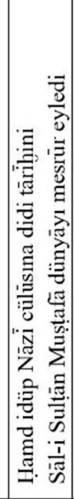 & 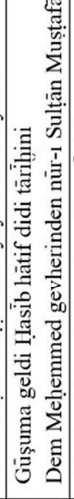 & 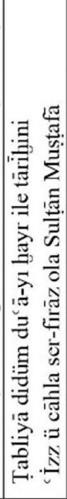 & 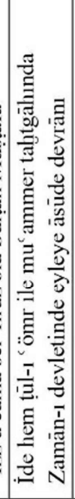 & 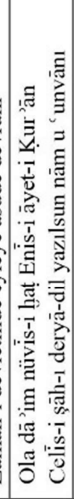 & 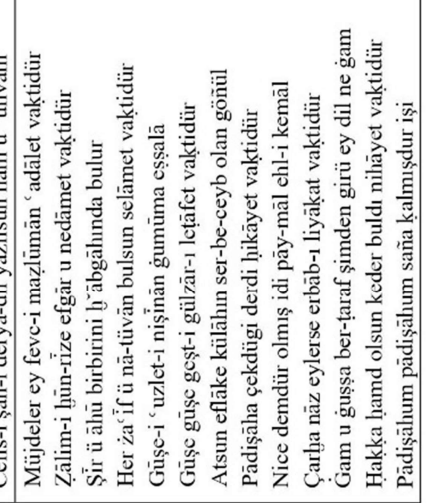 \\
\hline 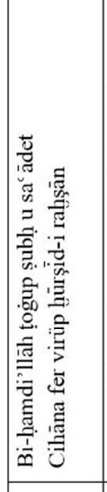 & 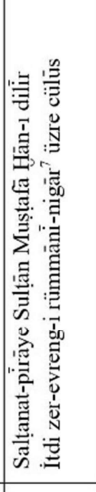 & 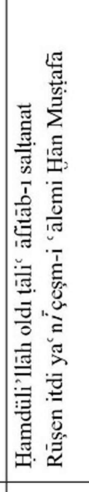 & 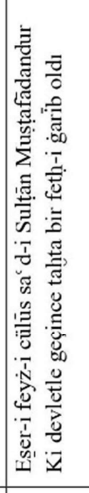 & 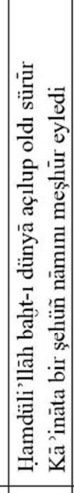 & 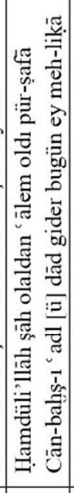 & & 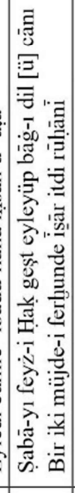 & 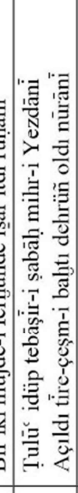 & 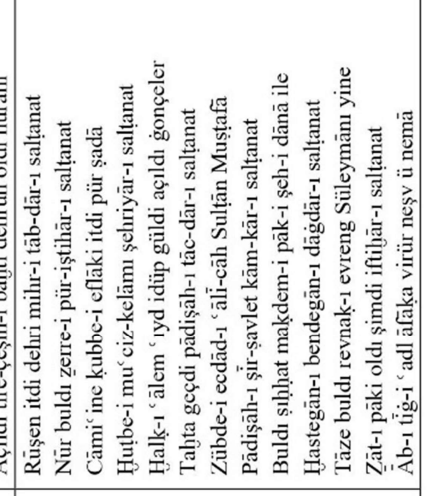 \\
\hline 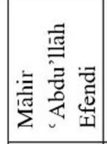 & & 胥 & 胥 & 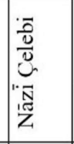 & & & & 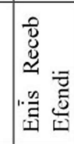 & 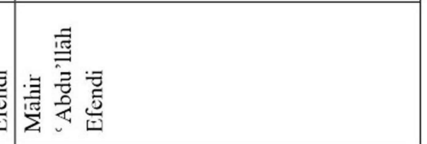 \\
\hline$\approx$ & 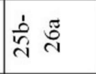 & הัّ & 密 & |c: & $\frac{1}{2}$ & ثิ & 离 & 它 & 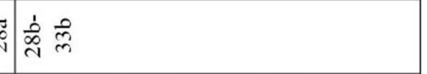 \\
\hline
\end{tabular}


492 / RumeliDE Journal of Language and Literature Studies 2020.19 (June)

The journal of poems which were made for Sultan Mustafa II / Z. Efe (pp. 46o-493)

\begin{tabular}{|c|c|c|c|c|c|c|c|c|c|c|c|c|c|c|c|}
\hline & 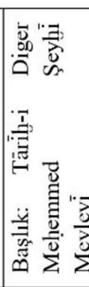 & 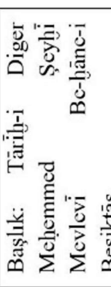 & 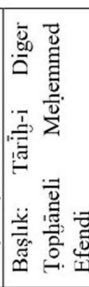 & 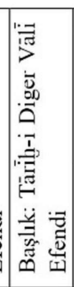 & 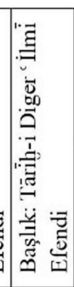 & 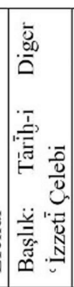 & 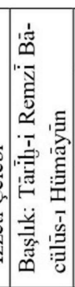 & 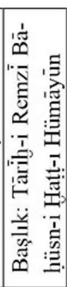 & 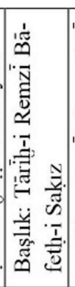 & 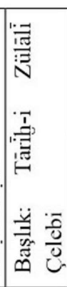 & 总 & 总 & 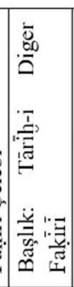 & 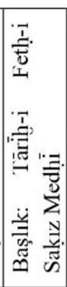 & 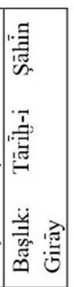 \\
\hline & . & 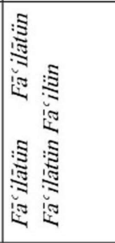 & 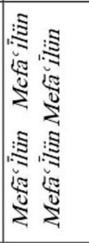 & 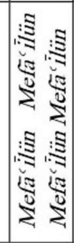 & 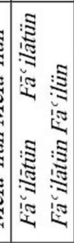 & 洁 & 新 & 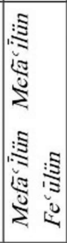 & 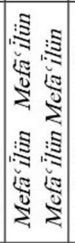 & 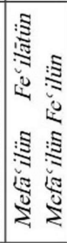 & 㱐 & 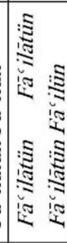 & 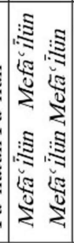 & & 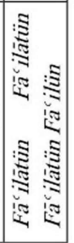 \\
\hline & . & 营 & 颜 & 胥 & 渞 & 湮 & 莺 & 焉 & : : & 鄫要 & 滈 & 莺 & 屋 & : & : : \\
\hline & & 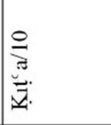 & 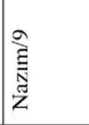 & 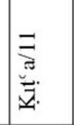 & 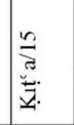 & 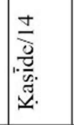 & $\frac{\frac{0}{3}}{\vec{z}}$ & 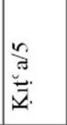 & 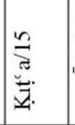 & 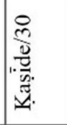 & 跑 & 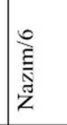 & 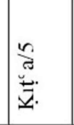 & 高 & 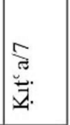 \\
\hline 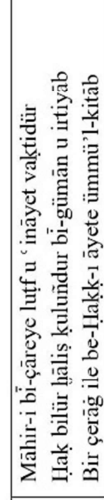 & 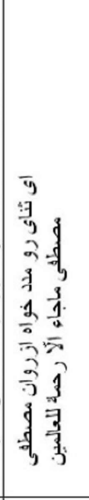 & 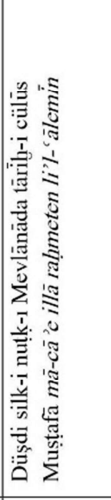 & 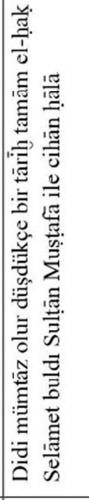 & 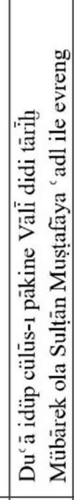 & 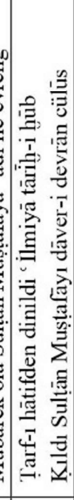 & 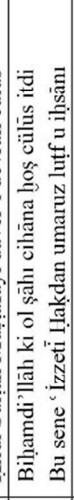 & 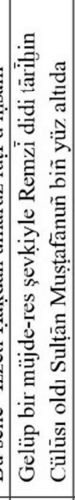 & 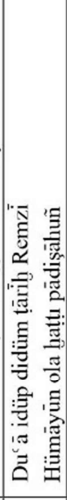 & 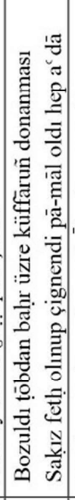 & 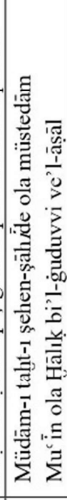 & $\frac{0}{0}$ & & 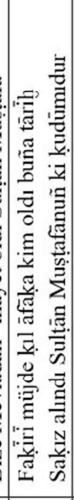 & & 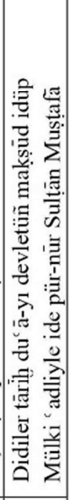 \\
\hline 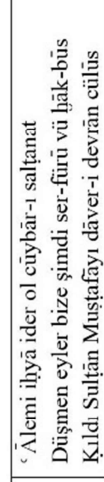 & 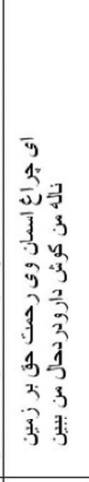 & 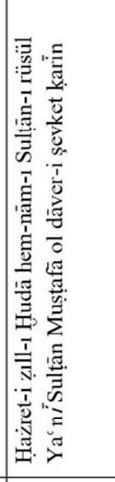 & 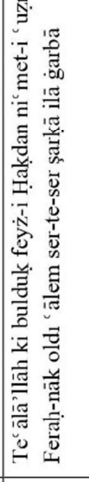 & 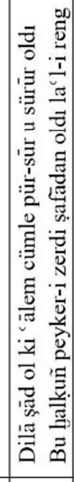 & 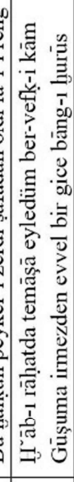 & 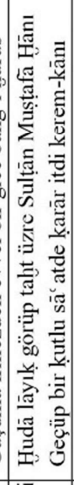 & 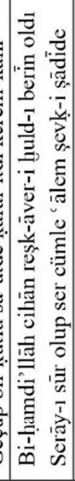 & 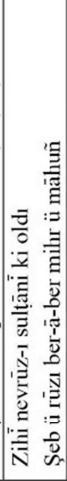 & 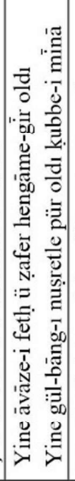 & 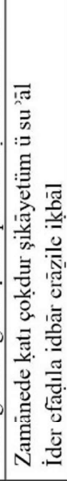 & 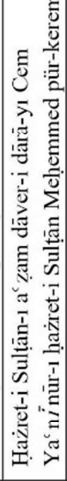 & & 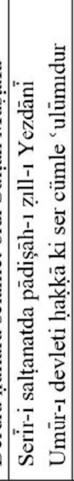 & & 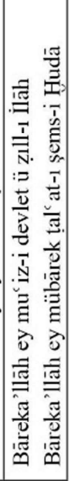 \\
\hline & 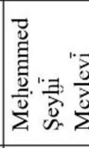 & 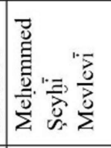 & 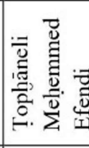 & : & 㺃 & 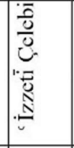 & | & 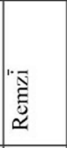 & |芯 & 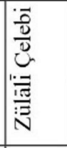 & & & |: & "吾" & 窟 \\
\hline & ล็๊ & ลें สิ & 㝘 & 产 。유 & 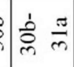 & $\frac{\dot{t}}{m}=0$ & 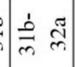 & लే & 씰 હే & $\dot{\vec{c}}=$ & 앙 f & 㞼 & 守 & & 寻 \\
\hline
\end{tabular}




\begin{tabular}{|c|c|c|c|c|c|c|c|c|c|}
\hline$x=$ & 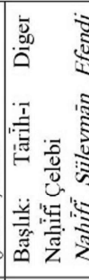 & 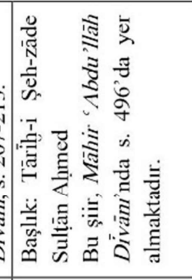 & 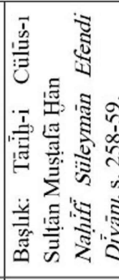 & 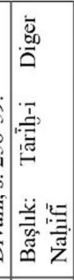 & 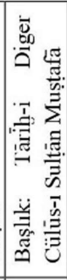 & 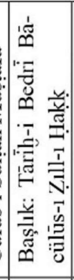 & 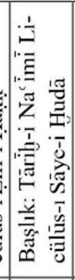 & 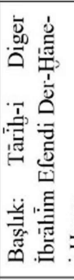 & 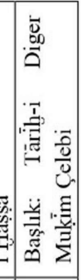 \\
\hline 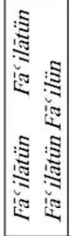 & 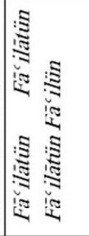 & 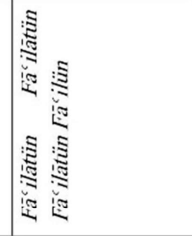 & 意 & 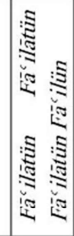 & 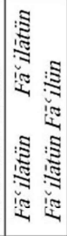 & 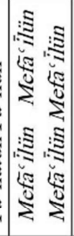 & 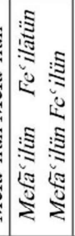 & 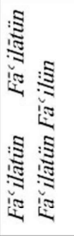 & \\
\hline $\bar{E}$ & 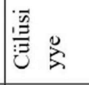 & : & 营 & 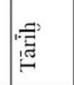 & : & 㴗 & 焉 & ": & \\
\hline$\frac{9}{5}$ & 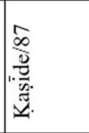 & 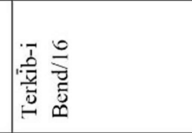 & 产 & 胥 & 离 & 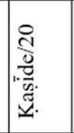 & $\overline{\bar{z}}$ & 翌 & 童 \\
\hline 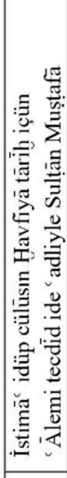 & 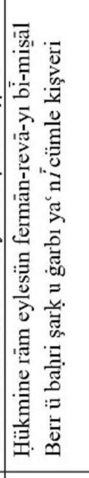 & 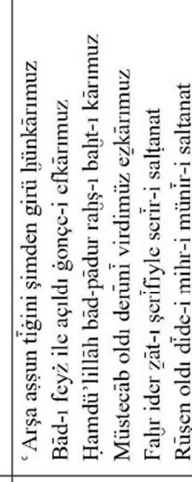 & 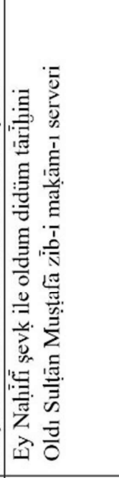 & & . & 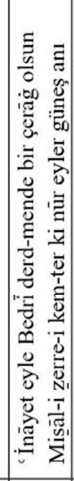 & 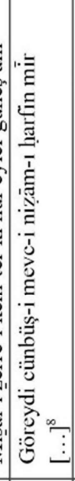 & 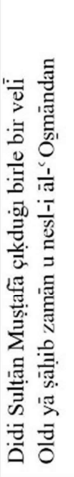 & \\
\hline 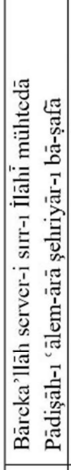 & 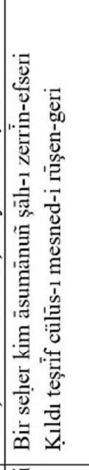 & 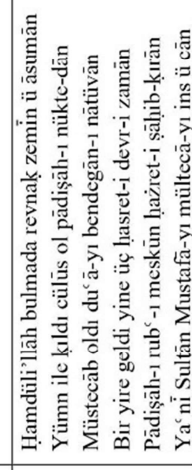 & 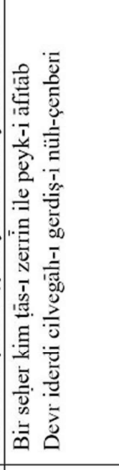 & 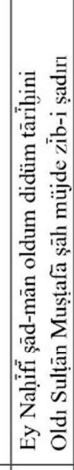 & & 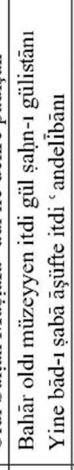 & 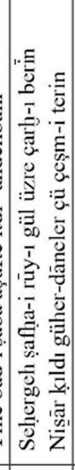 & 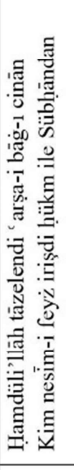 & 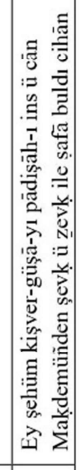 \\
\hline & & 疋 & 惕 & 惊. & & |": & | & 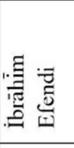 & \\
\hline 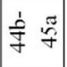 & 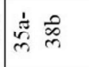 & 峞 $\frac{\Im}{7}$ & 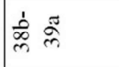 & లూ & §ू & 离 & 孚 & 字 亲 & \\
\hline
\end{tabular}

